\title{
Draposa, a new wolf spider genus from South and Southeast Asia (Araneae: Lycosidae)
}

\section{TORBJÖRN KRONESTEDT}

Department of Entomology, Swedish Museum of Natural History, Box 50007, SE-104 05 Stockholm, Sweden. E-mail: torbjorn.kronestedt@nrm.se

\begin{abstract}
Draposa gen. nov. is proposed for eight wolf spider species from the Indomalayan Region, all of which were previously placed in the genus Pardosa: Draposa atropalpis (Gravely,1924) comb. nov., D. lyrivulva (Bösenberg \& Strand, 1906) comb. nov. (=Pardosa leucopalpis Gravely, 1924 syn. nov.), D. nicobarica (Thorell, 1891) comb. nov., D. oakleyi (Gravely, 1924) comb. nov., D. porpaensis (U. A. Gajbe, 2004) comb. nov., D. subhadrae (Patel \& Reddy, 1993) comb. nov., D. tenasserimensis (Thorell, 1895) comb. nov., and D. zhanjiangensis (Yin, Wang, Peng \& Xie, 1995) comb. nov. Species of Draposa share synapomorphies in the copulatory organs, inter alia a complex subpaleal sclerite in the terminal part of the male bulbus. The presence of D. lyrivulva in Japan is put in doubt and the species should be excluded from the list of spiders in that country. Draposa nicobarica (type species) and D. tenasserimensis are redescribed and illustrated for the first time from the type material. Draposa atropalpis is redescribed from material from India and Sri Lanka, D. lyrivulva and D. subhadrae (first record outside India) from material collected in Sri Lanka and D. oakleyi from material from India and Bangladesh.
\end{abstract}

Key words: Taxonomy, Pardosa, Indomalayan region

\section{Introduction}

The world-wide spider family Lycosidae Sundevall, 1833 (wolf spiders) comprises 2367 currently recognised species, of which 526 species (with 22 additional intraspecific taxa) are assigned to the genus Pardosa C. L. Koch, 1847 (Platnick 2010). Among the South Asian species hitherto allocated to this genus, many remain poorly known and await morphological scrutiny of their copulatory organs in order to facilitate identification as well as further comparative systematic analyses.

Species of the speciose and heterogeneous genus Pardosa sensu lato have been described from all continents except Antarctica. Several of these species are placed in separate informal species groups, some of which are based on putative synapomorphies. The breakup of this vast assemblage of species commenced with the erection of the genus Wadicosa Zyuzin, 1985, preliminarily encompassing several species formerly placed in Pardosa or Lycosa Latreille, 1804 in the Old World (cf. Kronestedt 1987). Of the few species in Australia originally assigned to Pardosa, only P. pexa Hickman, 1944 remains in this genus (Platnick 2010). The original illustration of the palp of this species, however, shows it to belong to the subfamily Lycosinae Sundevall, 1833. Consequently, the genus Pardosa sensu lato is absent from Australia. Among the numerous African species formerly assigned to Pardosa, P. foveolata Purcell, 1903, along with some related species, were recently separated by Russell-Smith et al. (2007) in the genus Foveosa Russell-Smith, Alderweireldt \& Jocqué, 2007. Also recently, the genus Bogdocosa Ponomarev \& Belosludtsev, 2008 was erected for a newly described lycosid species from the Astrakhan area in Russia (Ponomarev et al. 2008). Further Asian species, currently placed in Pardosa, are candidates for transfer to Bogdocosa (T. Kronestedt \& Y.M. Marusik, unpublished data). 
The genus Pardosa has traditionally been placed in the subfamily Pardosinae Simon, 1898. Dondale (1986) defined this subfamily by two characters: 'terminal apophysis toothlike, situated retrolaterally on palea surface, with tip directed toward tip of embolus and of conductor' and 'conductor shaftlike, lying transversely along basal margin of palea'. These characters certainly define the genus Pardosa sensu stricto [type species: Lycosa alacris C. L. Koch, 1833 (Kronestedt et al. 2002)]. Dondale added that these characters may require 'modification when the other genera traditionally assigned to the subfamily are examined'. A comparison of different lycosid subfamilies based on morphological characters in the copulatory organs was given by Zyuzin (1993). For Pardosinae, the following characters in the male palp were emphasised: 'small depression in tegulum as bed for tip of resting embolus' and 'conductor consisting of thick well-sclerotised basal part of palea concealed by tegulum'. These characters also conform to genus Pardosa sensu stricto. Most recently, by analysing molecular data from an array of different lycosids, including a heterogeneous assemblage of species in Pardosa sensu lato, Murphy et al. (2006) questioned the validity of Pardosinae, which nested as a monophyletic clade within traditional members of the Lycosinae. Following this, Pardosa with phyletic allies should form a taxon on a subordinate intrafamilial level and Lycosinae be redefined. Here I refrain from placing Draposa gen. nov. in any of the currently accepted subfamilies pending further research in the higher phylogeny of wolf spiders.

Several years ago I collected material in Sri Lanka that I initially identified as Pardosa leucopalpis Gravely, 1924. Years later, Tanaka (1993) redescribed the female holotype of Pardosa lyrivulva (Bösenberg \& Strand, 1906) said to have been collected in Japan and originally described as belonging in Lycosa Latreille, 1804. Although the epigyne had been illustrated earlier (Yaginuma 1986), Tanaka's more precise drawing was essential for the recognition of this species. The very characteristic configuration of the epigyne was found to coincide with that of the specimens that I collected in Sri Lanka.

When studying the type series of Lycosa nicobarica Thorell, 1891 and L. tenasserimensis Thorell, 1895, as well as material from Sri Lanka fitting the description of Pardosa subhadrae Patel \& Reddy, 1993, it became evident that all these species are allied to P. lyrivulva based on morphological grounds. Pardosa atropalpis Gravely, 1924 and P. oakleyi Gravely, 1924 also share characters with the aforementioned species, although they are both considerably smaller in size compared with the rest.

The configuration of certain parts of the copulatory organs in P. lyrivulva and its abovementioned allies differs from that of corresponding parts in species of Pardosa sensu stricto, motivating a transfer to a separate new genus. Some years ago an allied species, viz. P. zhanjiangensis Yin, Wang, Peng \& Xie, 1995, was described from southern China. It is obvious from details given in the original description that the latter species is also a member of this new genus.

\section{Material and methods}

Material from the following collections has been studied:

BMNH Natural History Museum, London, United Kingdom

MZLU Zoological Museum, University of Lund, Lund, Sweden [material collected during the Lund University Ceylon Expedition in 1962 by P. Brinck, H. Andersson \& L. Cederholm (for description of localities see Brinck et al. 1971)]

NHRS Swedish Museum of Natural History, Stockholm, Sweden

SMF Senckenberg Museum, Frankfurt/M., Germany

ZMUC Zoological Museum, University of Copenhagen, Copenhagen, Denmark

ZMUT Zoological Museum, University of Turku, Turku, Finland

Some material will be deposited in the following collection:

ZMUM Zoological Museum, University of Moscow, Moscow, Russia 
Material deposited in the National Zoological Collection, Kolkata (India), was not examined. Gravely (1924) did not specify any type material, only added 'type' to one of his collection localities. Sinha (1951) listed the lycosid material, including the type material of Pardosa atropalpis Gravely, 1924, P. leucopalpis Gravely, 1924 and P. oakleyi Gravely, 1924, which was then present in the National Zoological Collection at Kolkata. This type material was also reported ("in spirit in good condition") in Tikader \& Malhotra (1980). Only syntypic material housed in BMNH of species described by Gravely (1924) was examined here.

SEM micrographs were taken by the author with a Hitachi S-4300 scanning electron microscope at the Swedish Museum of Natural History. Some of the digital photographs of specimens in ethanol were taken by Y.M. Marusik using an Olympus SZX12 stereomicroscope and an Olympus Camedia C-5050 camera at the Zoological Museum in Turku when I visited in March 2009; others were taken by the author using an identical stereomicroscope with an Olympus DP70 camera at the Department of Entomology at the Swedish Museum of Natural History.

Measurements refer to specified individuals and are given in mm except for the eyes. Eyepiece micrometer units (given for eyes) can be converted to $\mathrm{mm}$ by dividing by 80 . Eye row distances are as in Kronestedt (1975).

Comment on terminology. The use of descriptive terms for details in the terminal part of the male copulatory organ in lycosids has met with difficulties (Marusik et al. 2003). Functional terms like 'conductor' and topological terms like 'terminal apophysis' may refer to non-homologous structures in different genera. There is no controversy in the use of the terms embolus and palea, although varying apophyses and processes originating from the latter may not be homologous between genera. For comments on the descriptive terms introduced here, see the Description of the new genus below.

In describing the spermatheca, I rely on terms used by Sierwald (2000), viz. head of spermatheca (Fig. 30), recognized by its pores (Fig. 39), stalk of spermatheca (Fig. 30), and base of spermatheca. For two of the species (Draposa nicobarica and D. tenasserimensis) epigynes were not prepared as only original type series material was at hand.

Abbreviations (in italics used in figures). ALE, anterior lateral eye(s); AME, anterior median eye(s); a.pr, anterior subpaleal process; $c a v$, central cavity (=atrium); Cy, cymbium; emb, embolus; Fe, femur; $h s$, head of spermatheca, la.el, lateral elevation; Mt, metatarsus; pa.ap, paleal apophysis; Pt, patella; PLE, posterior lateral eye(s); PME, posterior median eye(s); p.pr, posterior subpaleal process; sep, septum; ss, stalk of spermatheca; sa.pt, subapical protrusion on tegular apophysis; Ta, tarsus; $t g . a p$, tegular apophysis; Ti, tibia.

\section{Taxonomy}

\section{Family Lycosidae Sundevall, 1833}

\section{Draposa gen. nov.}

Type species: Lycosa nicobarica Thorell, 1891.

Etymology. The name is an anagram of the name Pardosa. The gender is feminine.

Diagnosis. Males of Draposa gen. nov. differ from other lycosids by the presence of a subpaleal sclerite with two processes partly hidden by the palea in the terminal part of the bulbus, as well as by the tegular apophysis being transverse with wide basal part carrying variously shaped projections and narrow distal part carrying small subapical protrusion before evenly curved tip (e.g., Figs 13 \& 16); females differ by the epigyneal cavity being only partly divided by a tongue-like septum (e.g., Figs 19 \& 40).

Description. Lycosid spiders of small to medium size (carapace length approx. 2.00-4.55).

Carapace brownish with light brownish to yellowish median and lateral bands. Eye row I considerably shorter than eye row II. Eye row I slightly procurved, anterior median eyes slightly larger than anterior laterals (ØAME/ØALE 1.15-1.25). Chelicerae with rows of three retromarginal and three promarginal teeth, distalmost tooth in latter row small and knob-like (Fig. 36). Labium slightly wider than long. Leg lengths 
IV $>$ I $>$ II $>$ III or IV $>$ I $>$ III $>$ II. Mt IV as long as or shorter than Pt + Ti IV (measured dorsally). Ti I with three pairs of ventral spines (of which three are placed in an oblique line prolaterally). Male palp with subtegulum covered by wrinkled integument confluent with basal haematodocha (no lunar plate). Tegular apophysis prominent, transverse, without anteriorly directed branch as present in Pardosa sensu stricto. [A transverse tegular apophysis is also present in other Pardosa sensu lato groups, like the speciose Old World Pardosa nebulosa-group (Alderweireldt \& Jocqué 1992, Yin et al. 1997). In the latter, it differs from that of Draposa by being shorter and without protrusions as well as by terminating in a sclerotised hook-like tip]. Wide basal half of tegular apophysis with variously shaped projections, in several species tooth-like and more or less pointed. Narrow distal part with small subapical protrusion (e. g., Figs 13 \& 16) and distally tapering into narrow evenly curved tip. [A conductor as recognized in Pardosa (Kronestedt 1975; Dondale 1986; Dondale \& Redner 1990) is not present in Draposa.] Palea with retrolateral paleal apophysis (Fig.12; topological term not implying homology with somewhat similar condition, e.g., in Acantholycosa Dahl, $1908 \mathrm{cf}$. Marusik et al. 2003). Palea more or less covering subpaleal sclerite protruding into two prominent processes (Fig. 12), presumably unique feature for Draposa. Epigyne with deep central cavity (e. g., Figs 19 \& 40). Lateral elevations partly protruding over central cavity (in ventral view). Tongue-like septum protruding from in front into epigyneal cavity. Bottom of cavity extending laterad, covering all or most of spermathecae (in dorsal view: Figs 20, 22, 41, 43).

Species of Draposa gen. nov. have a 'pardosoid' appearance (i. e. being thin-legged, agile and diurnal, similar to species of Pardosa sensu stricto).

Remarks. Published illustrations indicate that there are species other than those treated in detail in this paper, which may qualify for transfer to Draposa: the males of both Pardosa aciculifera Chen, Song \& Li, 2001 (figs 4-7) from Hainan (China), and P. burasantiensis Tikader \& Malhotra, 1976 (fig. 12; Tikader \& Malhotra 1980, fig. 186) from West Bengal (India) apparently possess a subpaleal sclerite with apophyses mostly hidden by the palea in the terminal part of the bulbus as well as the shape of the tegular apophysis that is characteristic for species now placed in Draposa gen. nov. [The species referred to as $P$. burasantiensis from Yunnan and Hunan (China) in Yin et al. (1997: 239, fig. 112 ð̊) and Song et al. (1999: fig. 194C $\uparrow$ ), however, appears to belong to some species in the Pardosa nebulosa-group.] Pardosa amkhasensis Tikader \& Malhotra, 1976 (fig. 2; Tikader \& Malhotra 1980, fig. 177) and P. minutus Tikader \& Malhotra, 1976 (fig. 4; Tikader \& Malhotra 1980, fig. 147), both known only from females, should also be studied from the aspect of belonging in Draposa gen. nov.

Distribution. Indomalayan region: Pakistan, India, Sri Lanka, Bangladesh, Myanmar, China, Malaysia, Indonesia.

Draposa atropalpis (Gravely, 1924) comb. nov.

Figs 1, 2, 8, 9, 12-14, 19, 20, 23, 29

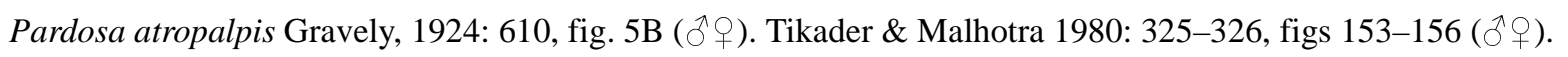

Type material. Syntypes of Pardosa atropalpis Gravely, 1924: $1 \overbrace{}^{\lambda}, 1+$, India, Tamil Nadu, Madras City

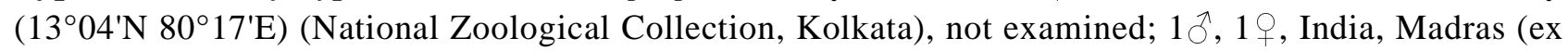
Madras Museum, BM 1924.V.13.18-19) (BMNH), examined.

Other material examined. SRI LANKA. Eastern: Kuchchaveli, $20 \mathrm{mi} \mathrm{NW}$ Trincomalee $\left(8^{\circ} 49^{\prime} \mathrm{N}\right.$ $81^{\circ} 06^{\prime} \mathrm{E}$ ), under branch on sandy ground, 10 February 1962 (loc. 60, Lund University Ceylon Expedition, MZLU), 1 \% . Southern: Hambantota $\left(6^{\circ} 07^{\prime} 30^{\prime \prime} \mathrm{N} 81^{\circ} 07^{\prime} 10^{\prime \prime} \mathrm{E}\right)$, dry grazed grassy area (short grass with scattered bushes), 23 February 1974 (T. Kronestedt, NHRS), $6{ }^{\lambda} 9$ \% ; E of Hambantota $\left(6^{\circ} 08^{\prime} 05^{\prime \prime} \mathrm{N}\right.$ $\left.81^{\circ} 08^{\prime} 30^{\prime \prime} \mathrm{E}\right)$, dry ground with very short vegetation and scattered bushes close to salt channel, 22 January 1974 (T. Kronestedt, NHRS), $3 \gtrsim 1$ \%

Diagnosis. Male distinguished by configuration of palp, notably shape of tegular apophysis with two acute protrusions wide apart (Fig. 8; cf. D. oakleyi: Fig. 10); female by shape of epigyne, notably short median septum in front (Fig. 9; cf. D. oakleyi: Fig. 11). 

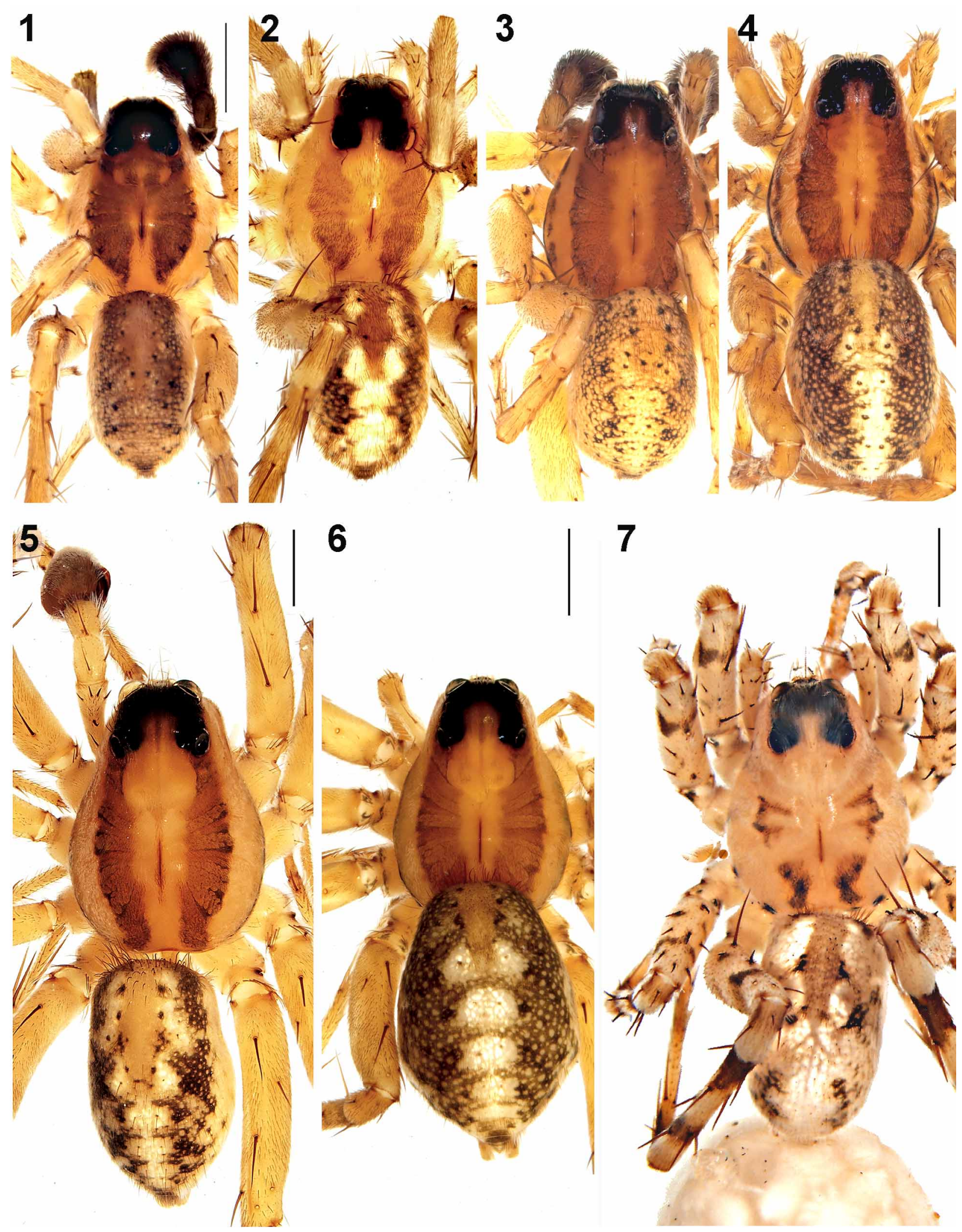

FIGURES 1-7. Habitus, dorsal view. 1, 2. Draposa atropalpis (Gravely) ${ }^{\lambda}(1)$ and $\rho$ (2) from Sri Lanka: Hambantota. 3, 4. D. oakleyi (Gravely) $\delta^{\lambda}$ (3) and $q$ (4) from India: Ootacamund. 5, 6. D. lyrivulva (Bösenberg \& Strand) $\partial^{\lambda}(5)$ and $\phi$ (6) from Sri Lanka: Matara (đ) and Ranna ()). 7. D. subhadrae (Patel \& Reddy) from Sri Lanka: Kuchchaveli. Scale line $1 \mathrm{~mm}$ (same for 1-4). 


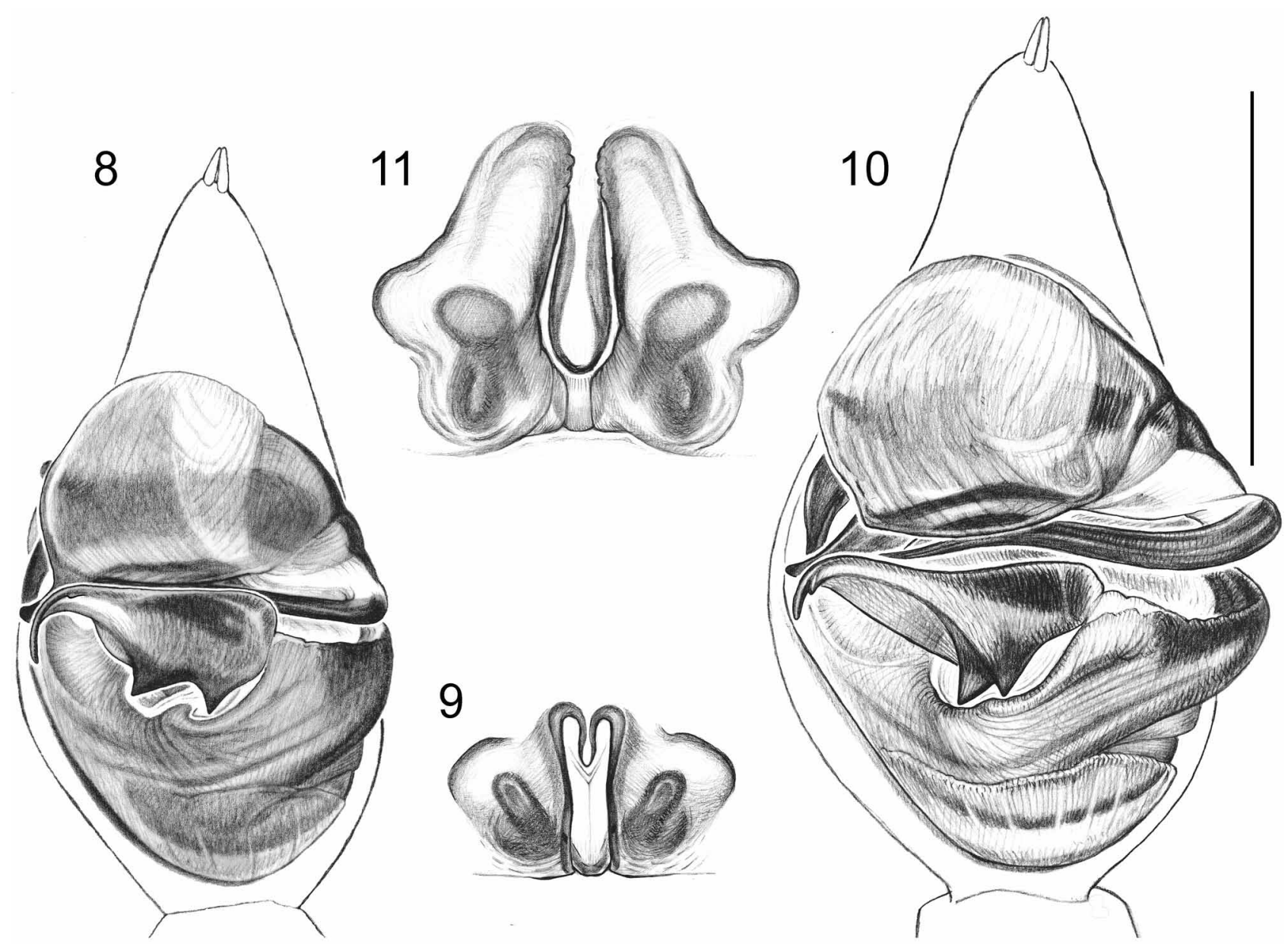

FIGURES 8-11. Right male palp $(8,10)$ and epigyne $(9,11)$. 8, 9. Draposa atropalpis (Gravely) from Sri Lanka: Hambantota. 10, 11. Draposa oakleyi (Gravely) from India: Ootacamund. Scale line $0.5 \mathrm{~mm}$.

Description. Male (from Hambantota, Sri Lanka). Total length 4.1. Carapace 2.20 long, 1.70 wide.

Prosoma (Fig. 1). Dorsum brown with yellow median band from fovea, widening backwards. Lateral bands yellow, wide, posteriorly confluent with median band. Marginal bands absent, only weak greyish spots above each leg coxa. Brown sides of thoracic part with pubescence of short dark and recumbent light hairs. Lateral bands mainly with recumbent whitish pubescence. Clypeus yellowish except for dusky brown spot below each ALE. Chelicerae yellowish, each with a longitudinal dusky brown stripe in front, confluent with dark spot on clypeus. Sternum light yellow, with recumbent white hairs and scattered erect greyish hairs.

Eyes. Width of row I 39, row II 59, row III 70, row II-III 58. Diameter of AME 10, ALE 7, PME 21, PLE 18. Distance between AME 5, between AME and ALE 2.

Opisthosoma (Fig. 1). Dorsum mottled in greyish and brownish shades with symmetrical pattern of scattered black dots. Lanceolate stripe indistinct, greyish-brown. Dorsum with dark erect and recumbent light hairs. Sides and venter yellowish with light pubescence (erect as well as recumbent hairs).

Legs (Table 1). Yellow, without annulation. Hairiness of leg I as in the other legs. Ti I with two retrolateral spines.

Palp (Figs 8, 12-14). Pt 0.45, Ti 0.50, Cy 1.10. All segments dusky brown with dark pubescence (hairs of varying length). Cymbium and bulbus comparatively narrow. Tegular apophysis with two well-separated and pointed projections (Fig. 13, cf. D. oakleyi: Figs 48, 49) and subapical protrusion (Fig. 13; latter hardly visible in ventral view). Protruding processes of subpaleal sclerite specific in shape (Fig. 12). Embolus widened in distal part before tapering to apex (Fig. 14).

Female (from Hambantota, Sri Lanka). Total length 4.5. Carapace 2.40 long, 1.80 wide. 

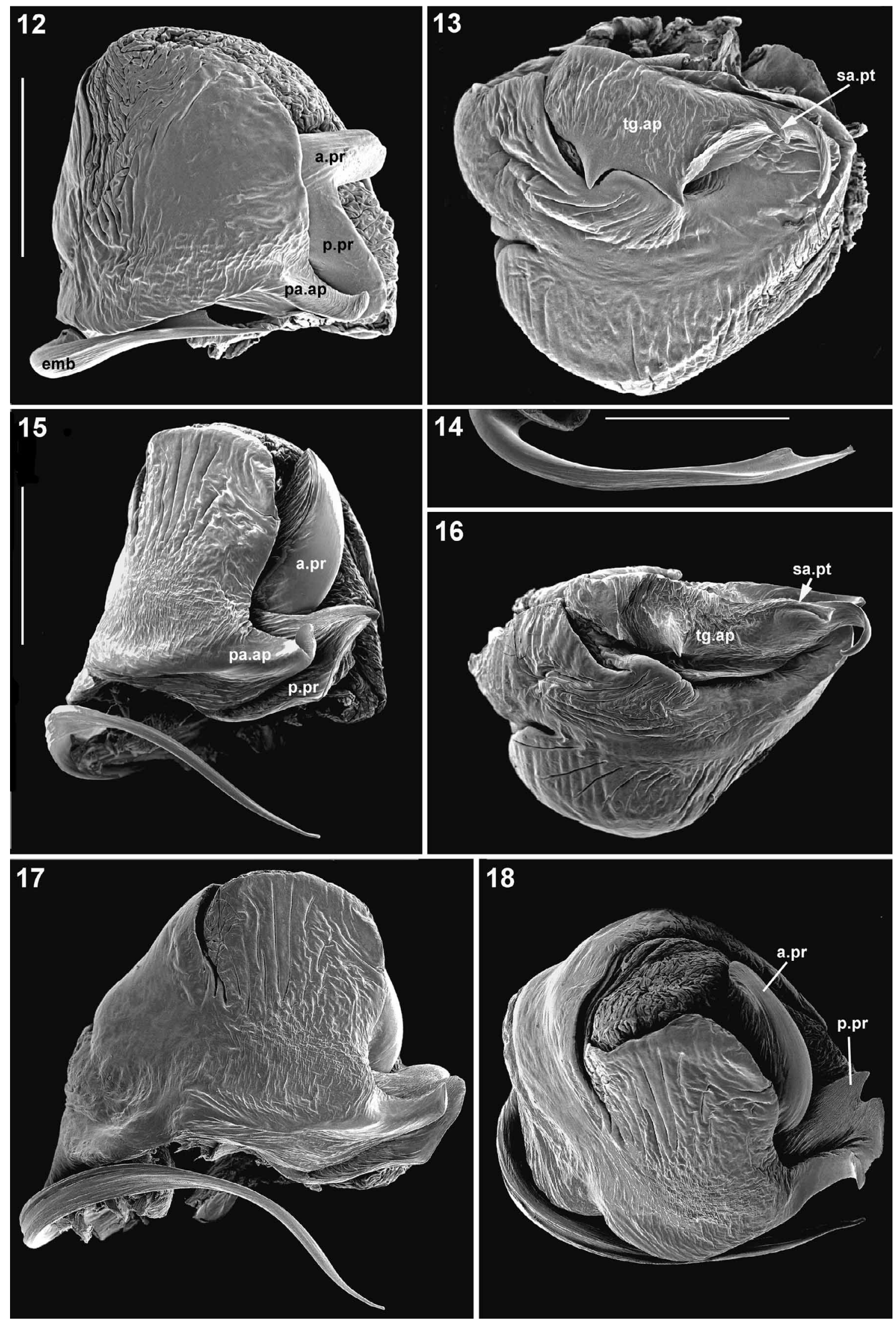

FIGURES 12-18. Parts of left male palp of Draposa atropalpis (Gravely) from Sri Lanka: Hambantota (12-14) and D. lyrivulva (Bösenberg \& Strand) from Sri Lanka: Inamaluwa (15-18). 12, 15, 17, 18. Terminal part in ventral (12, 17), obliquely retrolateral (15) and frontal (18) view. 13, 16. Tegulum in ventral view. 14. Embolus. Scale lines $200 \mu \mathrm{m}(12-$ 14 , same for $12 \& 13), 300 \mu \mathrm{m}(15-18$, same for all). 
Prosoma and opisthostoma (Fig. 2). Carapace with yellowish median band widening in front behind PLEs. Thoracic flanks lighter brown than in male. Lateral bands yellowish, wide, at margin with darker spots above coxae. Opisthosoma dorsally with wide median light brownish lanceolate spot, edges indented. Dorsal median band, sides and venter of opisthosoma light yellowish, with numerous whitish guanocytes visible through the cuticle. Sides of dorsum more or less brownish with scattered black dots.

Eyes. Width of row I 43, row II 64, row III 78, row II-III 63. Diameter of AME 10, ALE 7, PME 23, PLE 20. Distance between AME 6, between AME and ALE 2.

Legs (Table 1). Colour and spines as in male, Mt IV usually with dark brown ring apically.

Epigyne (Figs 9, 19, 20, 23, cleared Fig. 29). Median cavity opening comparatively narrow, in front divided by short narrow septum. Head of spermatheca close to base of spermatheca. Bottom of cavity characteristically shaped when seen in dorsal view (Fig. 20).

Size variation. Carapace length in males 2.00-2.35 ( $n=9)$, in females 2.15-2.50 ( $\mathrm{n}=10)$; tibia I vs. carapace length in Fig. 50.

Remarks. Gravely (1924) neither illustrated nor documented any particular details of the male apart from mentioning that "the palps [...] appear black throughout in spirit, but have the upper surface of the femora covered with ash-coloured pile, which shows only on drying". Tikader \& Malhotra (1980) did illustrate the male palp, but without showing enough specific details.

Distribution. India, Sri Lanka (Tikader \& Malhotra 1980).
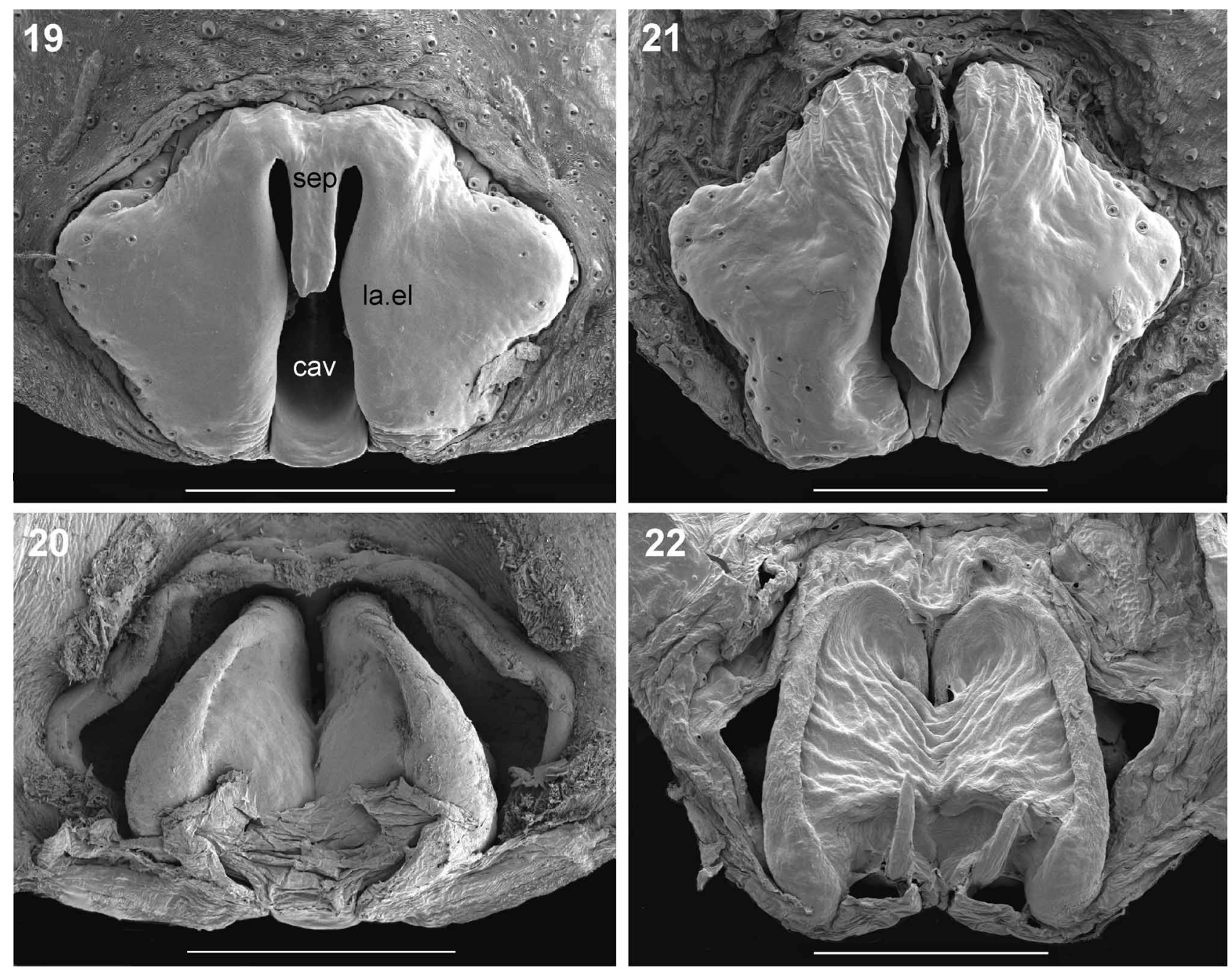

FIGURES 19-22. Epigynes in ventral $(19,21)$ and dorsal $(20,22)$ view. 19, 20. Draposa atropalpis (Gravely) from Sri Lanka: Hambantota (same epigyne in both views). 21, 22. D. oakleyi (Gravely) from India: Ootacamund (same epigyne in both views). Scale lines $250 \mu \mathrm{m}$. 

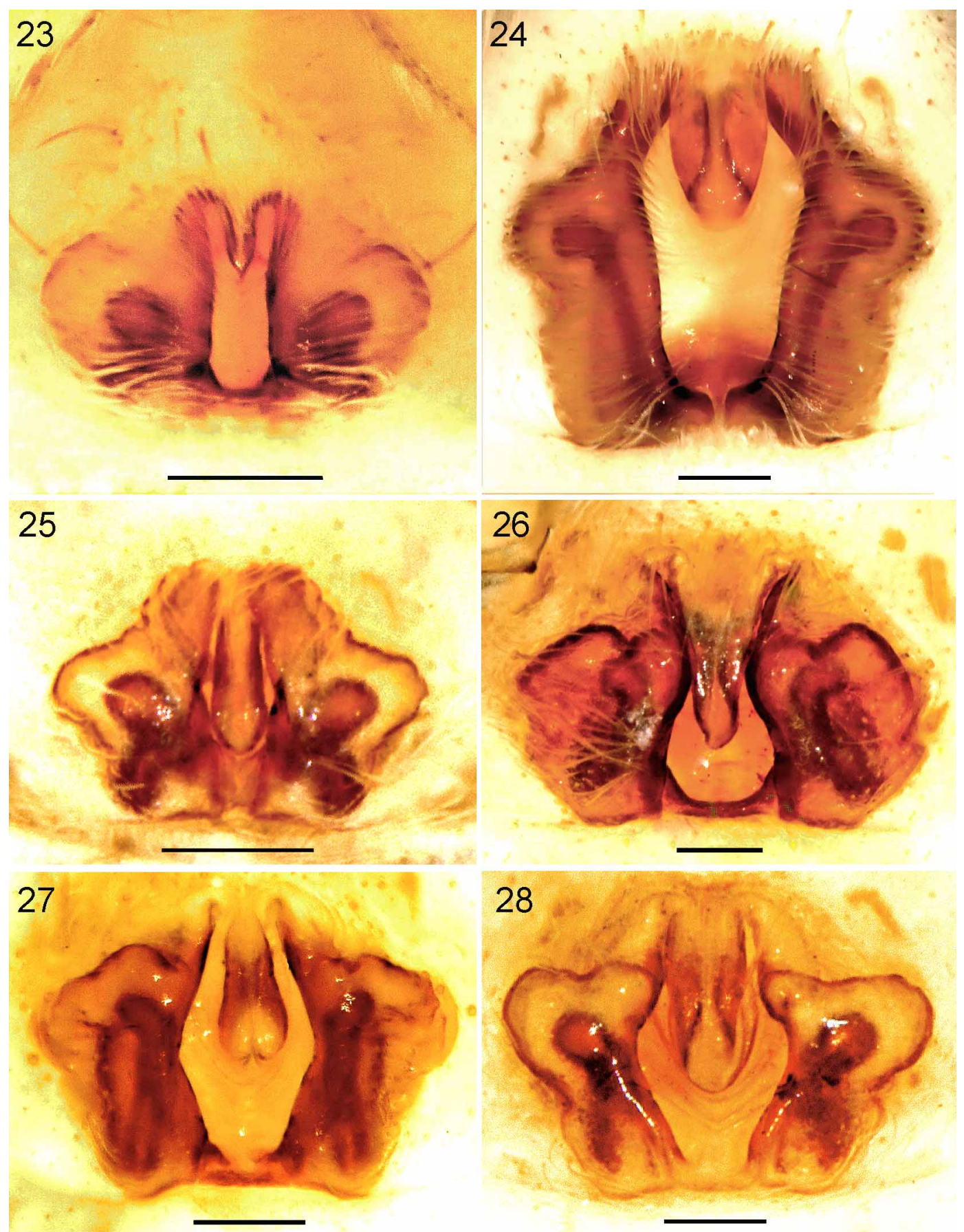

FIGURES 23-28. Epigynes in ventral view. 23. Draposa atropalpis (Gravely) from Sri Lanka: Hambantota. 24. D. lyrivulva (Bösenberg \& Strand) from Sri Lanka: Hambantota. 25. D. oakleyi (Gravely) syntype. 26. D. nicobarica (Thorell) from Nicobar Is., Nancowry. 27. D. subhadrae (Patel \& Reddy) from Sri Lanka: Kuchchaveli. 28. D. tenasserimensis (Thorell) from Myanmar: Southern Tenasserim. Scale lines $0.2 \mathrm{~mm}$.

\section{Draposa lyrivulva (Bösenberg \& Strand, 1906) comb. nov.}

Figs 5, 6, 15-18, 24, 30, 33-41

Lycosa lyrivulva Bösenberg \& Strand, 1906: 326 ()).

Pardosa lyrivulva: Yaginuma 1986: 165, fig. 90.10 ()); Tanaka 1993: 176-177, fig. 5 (); Tanaka 2009: 248, fig. 149 ( 9 , identical to previous reference).

Pardosa leucopalpis Gravely, 1924: 609-611, fig. 5D (ぷ+o). Tikader \& Malhotra 1980: 349-351, figs $203-206$ (ふึ우). Syn. nov. 
Type material. Holotype of Lycosa lyrivulva Bösenberg \& Strand, 1906: ${ }_{+}$, Japan, Kyushu, Saga, Kompira (labelled 'Japan, Saga, W. Dönitz S') (33¹9'28"N 130¹7'53"E) (SMF 2312), examined. Cf. Remarks below.

Syntypes of Pardosa leucopalpis Gravely, 1924: $1{ }^{\Uparrow}, 1$ 을 India, Tamil Nadu, Madras City $\left(13^{\circ} 04^{\prime} \mathrm{N}\right.$ $\left.80^{\circ} 17^{\prime} E\right)$ (National Zoological Collection, Kolkata), not examined.

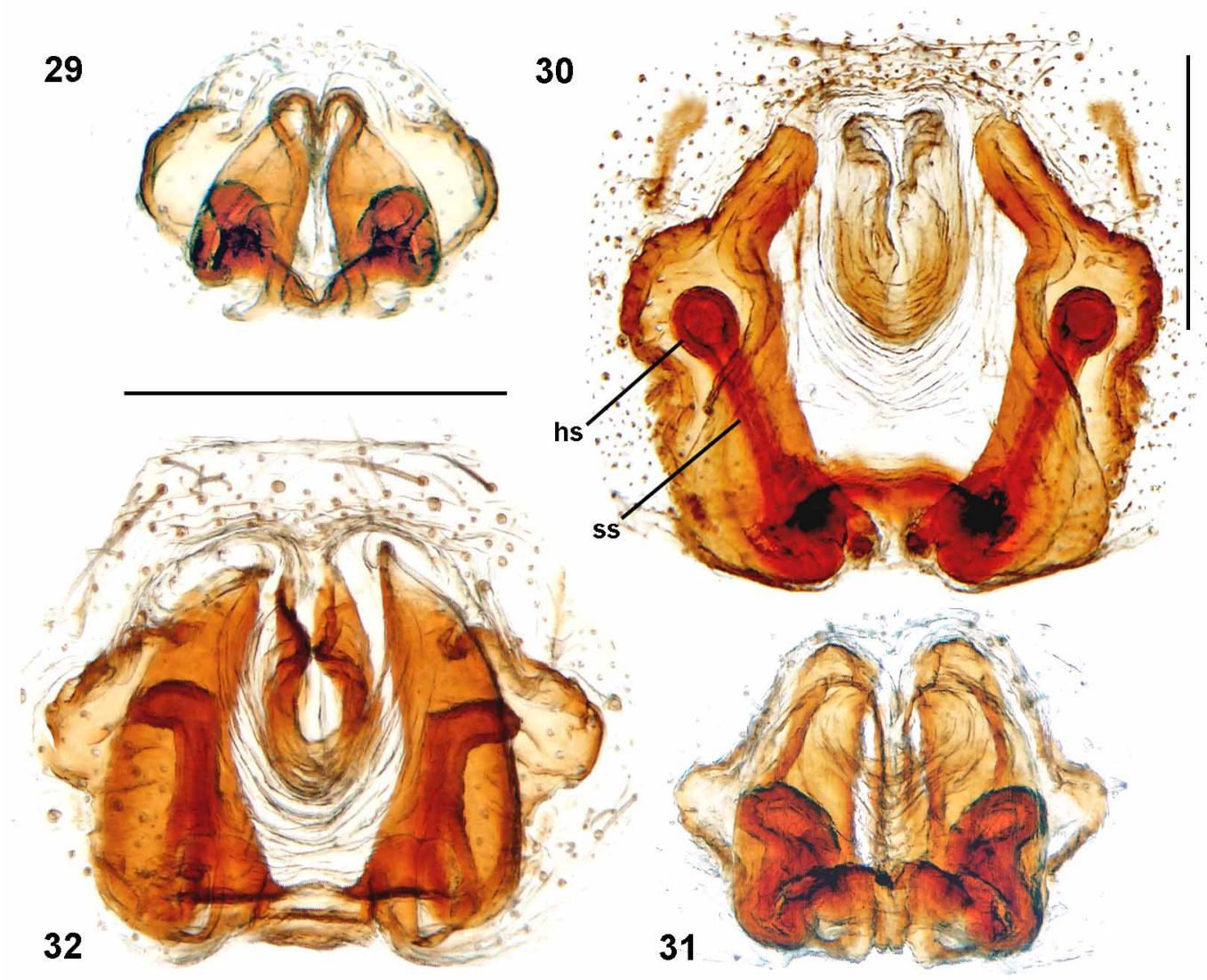

FIGURES 29-32. Epigynes, cleared, in dorsal view. 29. Draposa atropalpis (Gravely) from Sri Lanka: Hambantota. 30. D. lyrivulva (Bösenberg \& Strand) from Sri Lanka: Hambantota. 31. D. oakleyi (Gravely) from India: Ootacamund. 32. D. subhadrae (Patel \& Reddy) from Sri Lanka: Kuchchaveli. Scale lines $0.5 \mathrm{~mm}$ (vertical line refers to Fig. 30 , horizontal to remaining figures).

Other material examined. SRI LANKA. Central: Inamaluwa $\left(7^{\circ} 55^{\prime} 40^{\prime \prime} \mathrm{N} 80^{\circ} 40^{\prime} 45^{\prime \prime} \mathrm{E}\right)$, moist grazed grassland, 19 February 1974 (T. Kronestedt, NHRS), $3{ }^{\lambda} 3$. Western: Kalutara, 25 mi SSE Colombo (6 $\left.34^{\prime} 45^{\prime \prime} \mathrm{N} 79^{\circ} 57^{\prime} 40^{\prime \prime}\right)$, sandy beach, under stones, 25 January 1962 (loc. 19, Lund University Ceylon Expedition, MZLU), 2क; Stream 10 mi NNE Colombo (704'40"N 7953'40"E), 11 January 1962 (loc. 7, Lund University Ceylon Expedition, MZLU), 1 \%; Negombo (7¹2'30"N 7950'E), 24-26 November 1973 (M. Senaratne \& J. Haapasaari, ZMUT AA 8.035), 1 q. North Central: Minneriya Tank $\left(8^{\circ} 02^{\prime} \mathrm{N} 80^{\circ} 54^{\prime} \mathrm{E}\right)$, moist grazed grassland, 19 February 1974 (T. Kronestedt, NHRS), $1{ }^{\Uparrow} 5$. . Northern: Giant's Tank, 10 mi SE Mannar $\left(8^{\circ} 52^{\prime} \mathrm{N} 80^{\circ} 02^{\prime} \mathrm{E}\right.$ ), grassland (under stone), and in tin on beach, 15 February 1962 (loc. 83, Lund University Ceylon Expedition, MZLU), 2 ; Nay Aru at Pallamadu, at shore of stream, 10 mi E Mannar $\left(9^{\circ} 01^{\prime} \mathrm{N} 80^{\circ} 03\right.$ 'E), 15 February 1962 (loc. 86, Lund University Ceylon Expedition, MZLU ), $1 \delta^{\lambda}$ 우. Northwestern: Salt Pan, 3 mi N Puttalam $\left(8^{\circ} 04^{\prime} \mathrm{N} 79^{\circ} 49^{\prime} \mathrm{E}\right.$ ), under vegetable detritus, 1 February 1962 (loc. 41, Lund University Ceylon Expedition, MZLU), 4; Kadaimparu, $15 \mathrm{mi} N$ Negombo ( $\left.7^{\circ} 26^{\prime} \mathrm{N} 79^{\circ} 48^{\prime} 40^{\prime \prime} \mathrm{E}\right)$, sandy beach, 31 January 1962 (loc. 36), 2 . . Uva: Badulla district, Senanayake Samudra $\left(7^{\circ} 13^{\prime} \mathrm{N} 81^{\circ} 32^{\prime} \mathrm{E}\right.$ ), sandy slope, 21 November-17 December 1972 (P. Lehtinen \& L. Yapagedera, ZMUT AA 8.037), $2 \AA 1$; Badulla district, Inginiyagala $\left(7^{\circ} 13^{\prime} \mathrm{N} 81^{\circ} 32^{\prime} \mathrm{E}\right), 20$ November-20 December 1972 (S. Farook, ZMUT AA

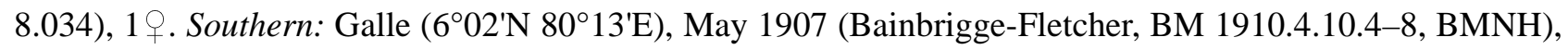
$1 \bigcirc^{\top} 4$; Yoda Wewa at Tissamaharama $\left(6^{\circ} 17^{\prime} 10^{\prime \prime} \mathrm{N} 80^{\circ} 13^{\prime} \mathrm{E}\right), 22$ March 1962 (loc. 169, Lund University 
Ceylon Expedition, MZLU), 19 ; Tissamaharama $\left(6^{\circ} 17^{\prime} \mathrm{N} 81^{\circ} 17^{\prime} 10^{\prime \prime} \mathrm{E}\right)$, at the tank, moist grassy area, 22 February 1974 (T. Kronestedt, NHRS), 3 ; ; E of Hambantota $\left(6^{\circ} 08^{\prime} 05^{\prime \prime} \mathrm{N} 81^{\circ} 08^{\prime} 30^{\prime \prime} \mathrm{E}\right)$, partly moist sandy sea

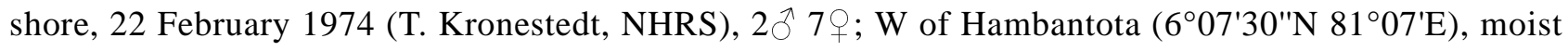
grazed grassy area at waterhole, 22 February 1974 (T. Kronestedt, NHRS), $6{ }^{\circ}$; Between Tangalla and Ranna

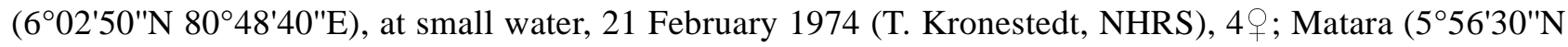
80³2'50"E), sea shore with boulders, 30 March 1973 (E. Kronestedt, NHRS), $1 \overbrace{}^{\Uparrow} 2$.

Diagnosis. Male distinguished by palp appearing a bit skew; by configuration of palp, notably shape of tegular apophysis, with two well separated pointed protrusions in proximal half (Fig. 33), as well as by oblique orientation of hairs on cymbium (Fig. 37; character shared with tenasserimensis); female distinguished by shape of epigyne (e. g., Figs $35 \& 40$ ), including corrugation of epigynal cavity bottom as seen from inside (dorsal view: Fig. 41), and long spermathecal stalks (Fig.30).
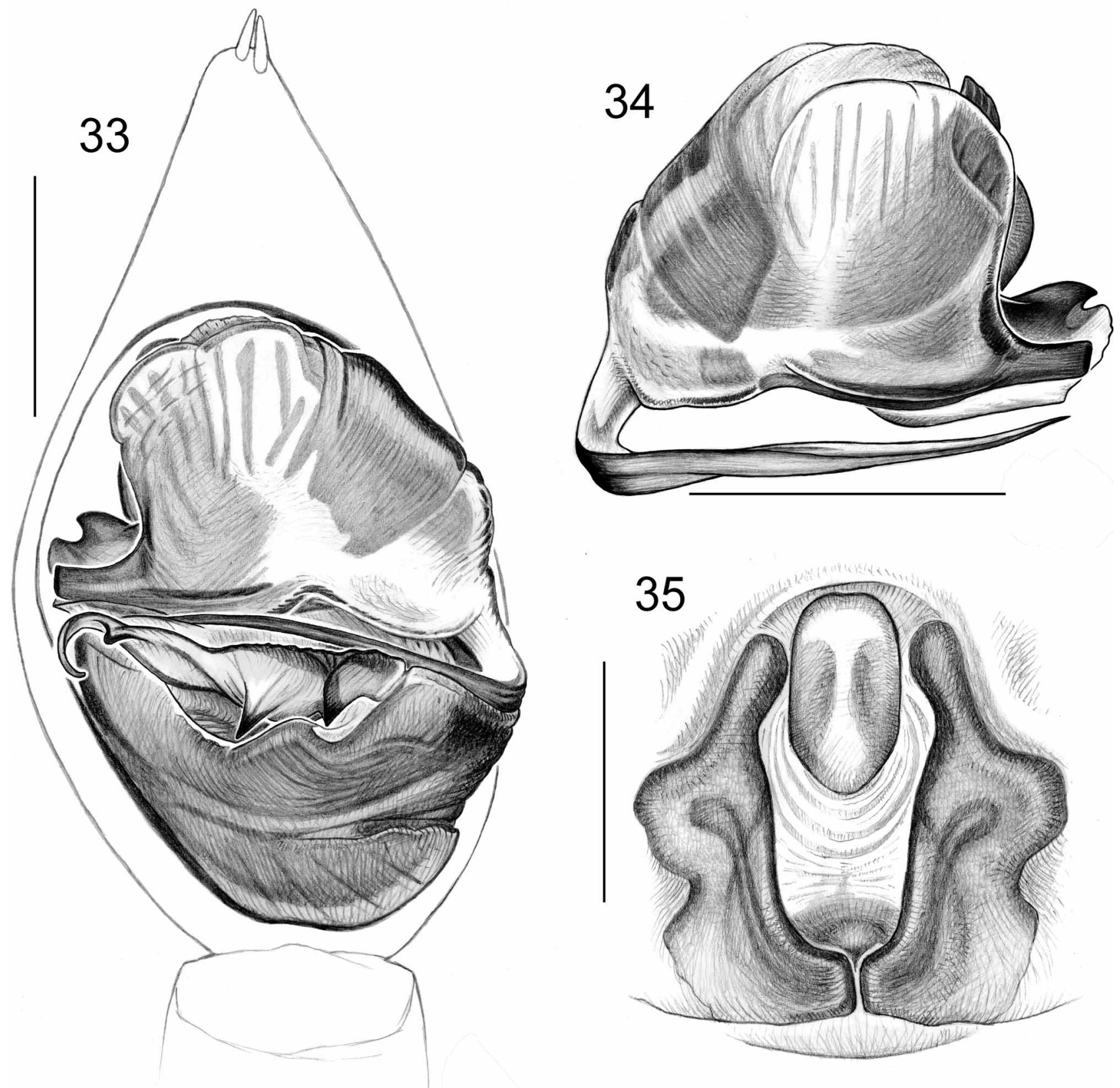

FIGURES 33-35. Draposa lyrivulva (Bösenberg \& Strand) from Sri Lanka: Hambantota $(33,35)$ and Minneriya Tank (34). 33. Right male palp, ventral view. 34. Terminal part of left male palp, ventral view. 35 . Epigyne. Scale lines 0.5 $\mathrm{mm}$. 

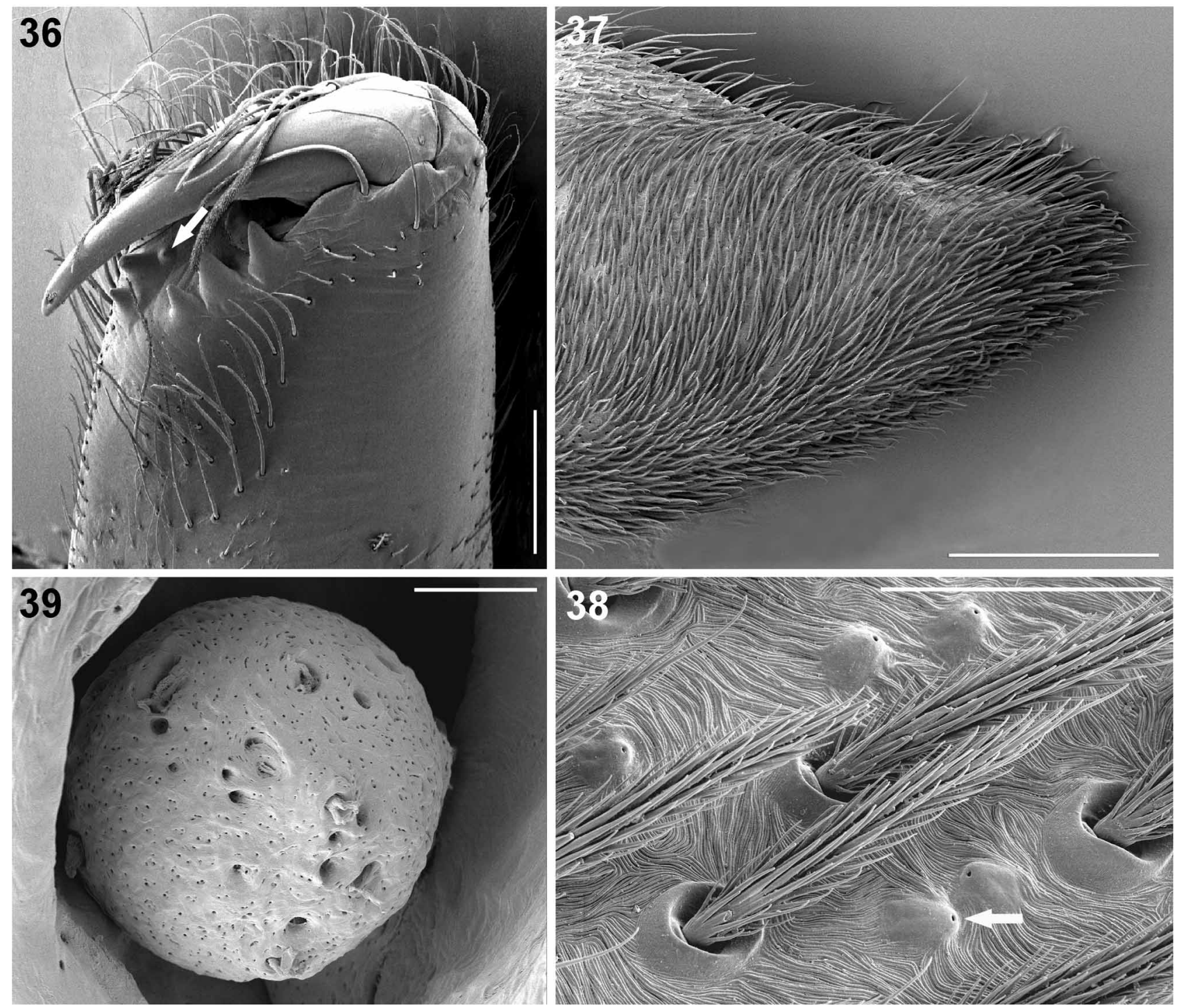

FIGURES 36-39. Draposa lyrivulva (Bösenberg \& Strand) from Sri Lanka: Hambantota. 36. Male chelicera (arrow points at small knob-like tooth in promarginal row). 37. Distal half of cymbium, note orientation of hairs. 38. Part of cymbium with numerous pores (arrow points at one pore). 39. Head of spermatheca with remains of channels opening into the lumen. Scale lines: $250 \mu \mathrm{m}(36), 500 \mu \mathrm{m}(37), 30 \mu \mathrm{m}(38,39)$.

Description. Male (from Hambantota, Sri Lanka). Total length 7.8. Carapace 4.25 long, 3.20 wide.

Prosoma (Fig. 5). Dorsum brown with distinct yellowish median band and wide distinct yellowish lateral bands, margins brownish. Median band with recumbent short dark and whitish hairs; sides dark-veined and with recumbent short dark and greyish hairs, lateral bands with whitish hairs. Clypeus more or less brownish below eye row I, otherwise yellowish. Chelicerae yellowish brown (sometimes with longitudinal faintly greyish brown markings) and furnished with scattered long dark hairs and numerous long pale thin hairs. Sternum light yellow, with scattered erect dark hairs and numerous more recumbent light hairs.

Eyes. Width of row I 65, row II 96, row III 123, row II-III 94. Diameter of AME 15, ALE 12, PME 38, PLE 32. Distance between AME 8, between AME and ALE 3.

Opisthosoma (Fig. 5). Dorsum pigmented in dark greyish with numerous yellowish dots. Lanceolate stripe greyish-brown. Posteriorly a row of yellowish spots beginning with a pair of spots at posterior end of lanceolate stripe. Dorsum covered with numerous long and short dark hairs and thin recumbent light hairs. Venter light yellowish with scattered light greyish and numerous recumbent whitish hairs.

Legs (Table 1). Yellowish, faintly tinged in greyish. Sometimes with very faint traces of annulation on tibiae and metatarsi. Hairiness of leg I as in the other legs. Ti I with two retrolateral spines. 

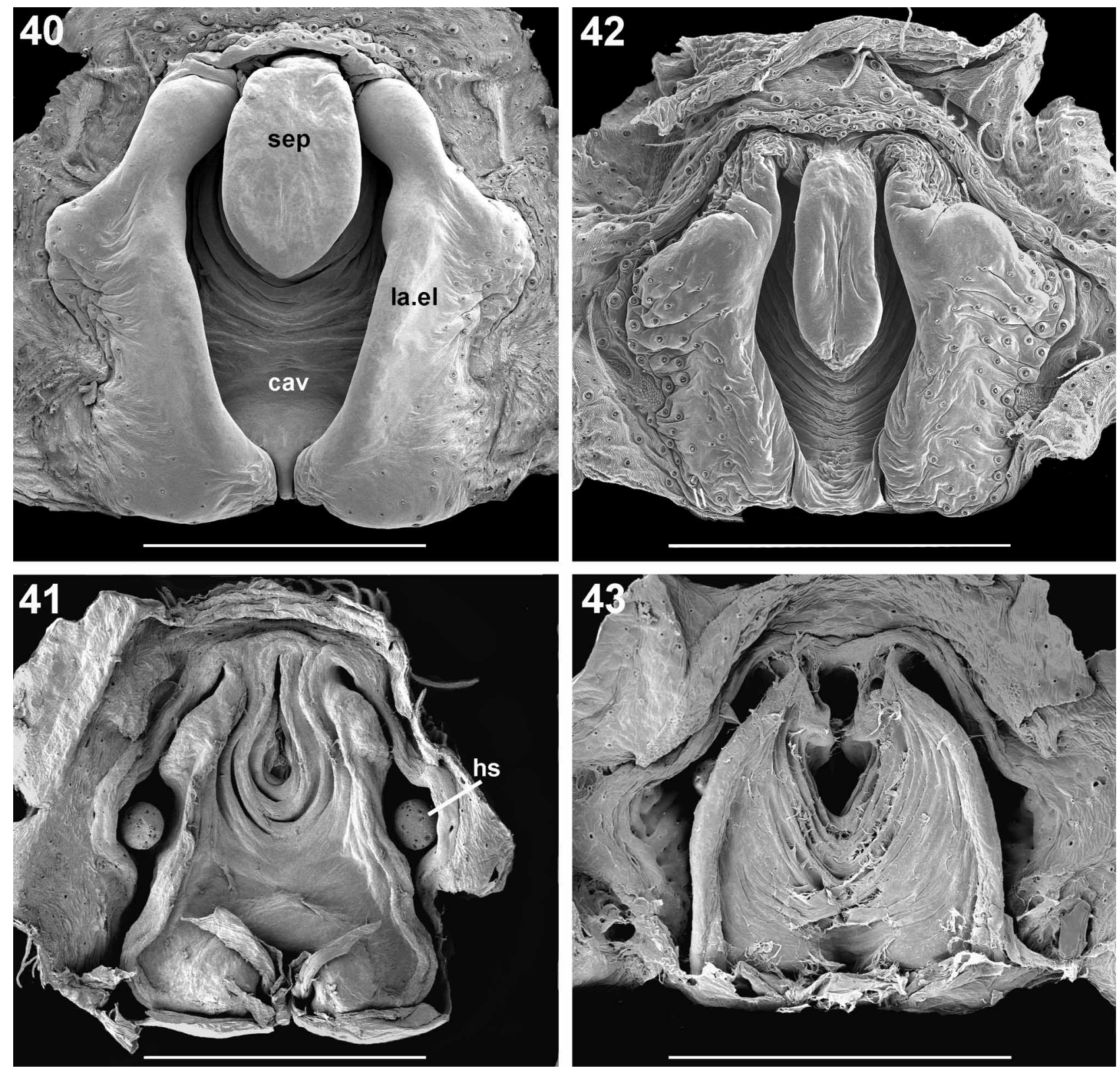

FIGURES 40-43. Epigynes in ventral $(40,42)$ and dorsal $(41,43)$ view. 40, 41. Draposa lyrivulva (Bösenberg \& Strand) from Sri Lanka: Hambantota. 42, 43. D. subhadrae (Patel \& Reddy) from Sri Lanka: Kuchchaveli (same epigyne in both views). Scale lines $500 \mu \mathrm{m}$.

Palp (Figs 15-18, 33, 34, 37, 38). Pt 0.80, Ti 0.70, Cy 1.90. Femur, patella and tibia yellowish, cymbium brownish. Entire palp appears a bit skew (Fig. 33) as reflected in oblique orientation of dorsal hairs on cymbium (Fig. 37). Widest part of cymbium somewhat flattened.in retrolateral part. Cymbium, notably retrolateral part, and tibia with numerous pores of type described by Kronestedt (1986) and further studied by Juberthie-Jupeau et al. (1990) (Fig. 38).

Female (from Hambantota, Sri Lanka). Total length 7.1 (carried egg sac). Carapace 3.65 long, 2.80 wide.

Prosoma and opisthosoma (Fig. 6). Similar to male in colouration and hairiness.

Eyes. Width of row I 60, row II 84, row III 108, row II-III 81. Diameter of AME 14, ALE 12, PME 32, PLE 26. Distance between AME 6, between AME and ALE 2.

Legs (Table 1). Yellowish, faintly tinged in greyish, sometimes with pronounced and dictinct annulation.

Epigyne (Figs 24, 35, 40, 41, cleared Fig. 30). Conspicuous deep median cavity, opening longer than wide, divided only in front by tongue-like septum. Lateral elevations with rims protruding over epigynal 
cavity; rims posteriorly converging, leaving narrow opening in between (cf. P. subhadrae). Bottom of cavity corrugated in a pattern as shown in dorsal view (Fig. 41). Spermathecae with very long stalk and small, globular head (Fig. 30).

Size variation. Carapace length in males 3.15-4.55 ( $n=8)$, in females 2.75-3.95 $(n=20)$; tibia I vs. carapace length in Fig. 50. The variation in size is unusually wide.

Remarks. Gravely (1924) neither illustrated nor documented any particular details of the male apart from describing the pilosity of the palp. Tikader \& Malhotra (1980) did illustrate the male palp, but without showing sufficient specific details.

It is remarkable that Pardosa lyrivulva has not been recorded in Japan since it was described based on a single female said to have been collected on Kyushu (Bösenberg \& Strand 1906). If widely distributed in SE Asia, it should have been taken at least in some more localities. I perceive its occurrence in Japan as erroneous. This is the only lycosid species newly described in Bösenberg \& Strand (1906) without illustration. According to Strand (in Bösenberg \& Strand 1906: 326) the illustrations pertaining to this species seemed to have been lost. Maybe there is a possibility that the locality label and the holotype mismatch due to some confusion long ago. According to the preface by E. Strand (Bösenberg \& Strand 1906), he studied the material collected in the 1880s by W. Dönitz in Japan while staying in the 'Königliches Naturalien-Kabinett' in Stuttgart (Germany). At that time, Strand also treated other spider material housed in the same museum among which was a collection of spiders from Sri Lanka collected by Redemann (Strand 1907, 1909). It is very unlikely that the record from Japan is due to an unintentional introduction.

Although no syntypes have been examined, it is clear from illustrations and other available material that Pardosa leucopalpis, with its very characteristic configuration of the epigyne, is conspecific with $P$. lyrivulva and here considered a junior synonym of the latter.

Distribution. Pakistan, India, Sri Lanka (record from Japan doubtful, see Remarks above).

\section{Draposa nicobarica (Thorell, 1891) comb. nov.}

Figs 26, 51, 52

Lycosa nicobarica Thorell, 1891: 5, 68 (§゚)

Pardosa nicobarica: Roewer 1955: 183.

Type material. Lectotype (here designated) of Lycosa nicobarica Thorell, 1891: §, India, Nicobar Islands, Kar Nikobar $\left(9^{\circ} 10^{\prime} \mathrm{N} 92^{\circ} 46^{\prime} \mathrm{E}\right)$ (ZMUC), examined. Paralectotypes of Lycosa nicobarica Thorell, 1891: 10, India, Nicobar Islands, Pulo Milu ( $\left.7^{\circ} 24^{\prime} \mathrm{N} 93^{\circ} 41^{\prime} 20^{\prime \prime} \mathrm{E}\right)$ (ZMUC); 1 \% , India, Nicobar Islands, Teressa $\left(8^{\circ} 15^{\prime} \mathrm{N}\right.$ $\left.93^{\circ} 06^{\prime} \mathrm{E}\right)(\mathrm{ZMUC}) ; 1+$, India, Nicobar Islands, Nancowry [Nanchovry] $\left(7^{\circ} 58^{\prime} \mathrm{N} 93^{\circ} 33^{\prime} \mathrm{E}\right)$ (Collectio Thorell No. 245/1538, NHRS), all examined.

The syntype material was collected by the Danish expedition travelling aboard the corvette 'Galathea' (circumnavigation 1845-1847). The Nicobar Islands were held by Denmark in periods between 1756 and 1868, and the 'Galathea' expedition visited the islands in the beginning of 1846.

Diagnosis. Male distinguished by palp being comparatively wide and by configuration of palp, notably length and shape of tegular apophysis, with one conspicuous tooth-like projection at about half its length (also so in $D$. tenasserimensis but latter species with comparatively shorter tegular apophysis); female by shape of epigyne, with septum comparatively long and wide at base and opening to cavity widening posteriad.

Description. Male (from Pulo Milu, Nicobar Is., India): Total length 6.8. Carapace 3.90 long, 2.90 wide. Prosoma. Both examined males discoloured by poor preservation.

Eyes. Width of row I 62, row II 88, row III 114, row II-III 85. Diameter of AME 14, ALE 12, PME 35, PLE 29. Distance between AME 6, between AME and ALE 2.

Opisthosoma. Both original males more or less discoloured by poor preservation.

Legs (Table 1). Unicolorous yellow (discoloured). Two retrolateral spines on TiI.

Palp (Fig. 51). Pt 0.70, Ti 0.60, Cy 1.80. Dorsal hairs on cymbium running lengthwise, as is usual in lycosids (not obliquely as in D. lyrivulva and D. tenasserimensis). Palp comparatively broad, tegular 
apophysis long, with conspicuous tooth-like projection at about half its length. Embolus narrow, evenly tapering to tip.

Female (from Teressa, Nicobar Is.): Total length 7.2. Carapace 3.90 long, 3.00 wide.

Prosoma. Discoloured but pattern discernible: wide yellowish median band, brownish thoracic sides and wide yellowish lateral bands extending to carapace edge.

Eyes. Width of row I 63, row II 92, row III 120, row II-III 90. Diameter of AME 14, ALE 12, PME 36, PLE 30. Distance between AME 8, between AME and ALE 3.

Opisthosoma. Discoloured, dorsum with discernible lanceolate stripe.

Legs (Table 1). As male.

Epigyne (Figs 26, 52). Conspicuous median cavity deep, opening widening backwards, more so in female from Nancowry (Fig. 26). Median septum wide, long, extending backwards to about $2 / 3$ of the cavity length. In female from Nancowry (Fig. 26), median septum widening more anteriad than in epigyne of female from Teressa (Fig. 52). Spermathecae elongated, visible through cuticle of lateral elevations.

Size variation. Carapace length of lectotype male 4.20, of female from Nanchovry 4.00.

Remarks. The spider fauna of the Nicobar Islands has been documented by Thorell (1891) and Tikader (1977). The lycosid species recorded by Thorell (1891) were Pardosa (sub Lycosa) nicobarica and P. (sub L.) thalassia (Thorell, 1891), both so far known as endemic to these islands [none of them were recorded by

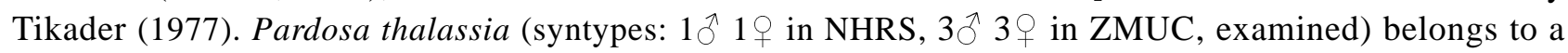
separate species group including, among others, Pardosa annandalei (Gravely, 1924) and Pardosa pseudoannulata (Bösenberg \& Strand, 1906).

Distribution. India: Nicobar Islands.

\section{Draposa oakleyi (Gravely, 1924) comb. nov.}

Figs 3, 4, 10, 11, 21, 22, 25, 31, 44-49

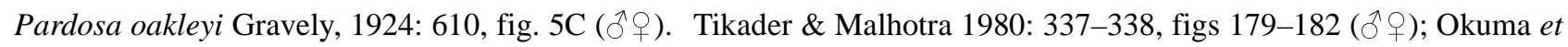
al. 1993: 51, fig 45B (P).

Pardosa lahorensis Dyal, 1935: 145-146, pl. 13 figs 43-44 (ð̊) ). Sadana 1971: 107, fig. 3 (ð)). Synonymy established in Tikader \& Malhotra (1980).

Type material. Syntypes of Pardosa oakleyi Gravely, 1924: 1 1 , 1 , India, Tamil Nadu, Ootacamund (ca $11^{\circ} 24^{\prime} \mathrm{N} 76^{\circ} 41^{\prime} \mathrm{E}$ ) (National Zoological Collection, Kolkata), not examined. $1+$, India, Nilgiris, Ootacamund, 6400-8000 ft, 20-30 May 1921 (Gravely, BM 1924.V.13.20-21) (BMNH, ex Madras Museum), examined.

Syntypes of Pardosa lahorensis Dyal, 1935: depository unknown.

Other material examined. INDIA. Chandigarh: Chandigarh (ca 30 $44^{\prime} \mathrm{N} 76^{\circ} 46^{\prime} \mathrm{E}$ ), from grassy ground, 14 October 1965 (BMNH), $20^{3} 2$ ․ Punjab: Ludhiana (ca 3054'N 7651'E), 10 April 1974 (G. L. Sadana. NHRS), 1 \%; Patiala City (30²1'N 76²7'E), University Campus, 3-8 May 1999 (Y. M. Marusik, NHRS,

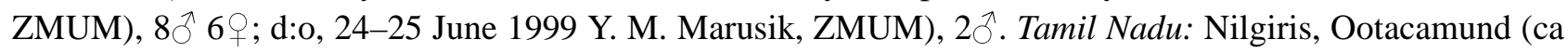
$11^{\circ} 24^{\prime \prime} \mathrm{N} 76^{\circ} 41^{\prime} \mathrm{E}$ ), $2450 \mathrm{~m}$ asl, grassy mountain slope, 22 April 1979 (P. T. Lehtinen, NHRS, ZMUT), $2 \bigcirc^{\lambda} 9$. BANGLADESH.: Rajshahi: Rajshahi (ca $24^{\circ} 23^{\prime} \mathrm{N} 88^{\circ} 37^{\prime} \mathrm{E}$ ), grassy dry lawn, 4 November 1973 (A. Islam, ZMUT), 4 .

Diagnosis. Male distinguished by configuration of palp, notably shape of tegular apophysis with two close acute protrusions (Fig. 10; cf. D. atropalpis: Fig. 8); female by shape of epigyne, notably long median septum almost covering opening of median cavity (Fig. 11; cf. D. atropalpis: Fig. 9).

Description. Male (from Ootacamund, India). Total length 4.4, carapace 2.55 long, 1.90 wide.

Prosoma (Fig. 3). Dorsum brown with yellow median and lateral bands, marginal bands brownish grey, more or less broken into blotches. Margin black. Clypeus yellowish, with white pubescence. Chelicerae yellowish with greyish brown longitudinal stripes. Sternum yellowish, slightly greyish brown.

Eyes. Width of row I 42, row II 61, row III 77, row II-III 60. Diameter of AME 10, ALE 8, PME 24, PLE 18. Distance between AME 6, between AME and ALE 2. 

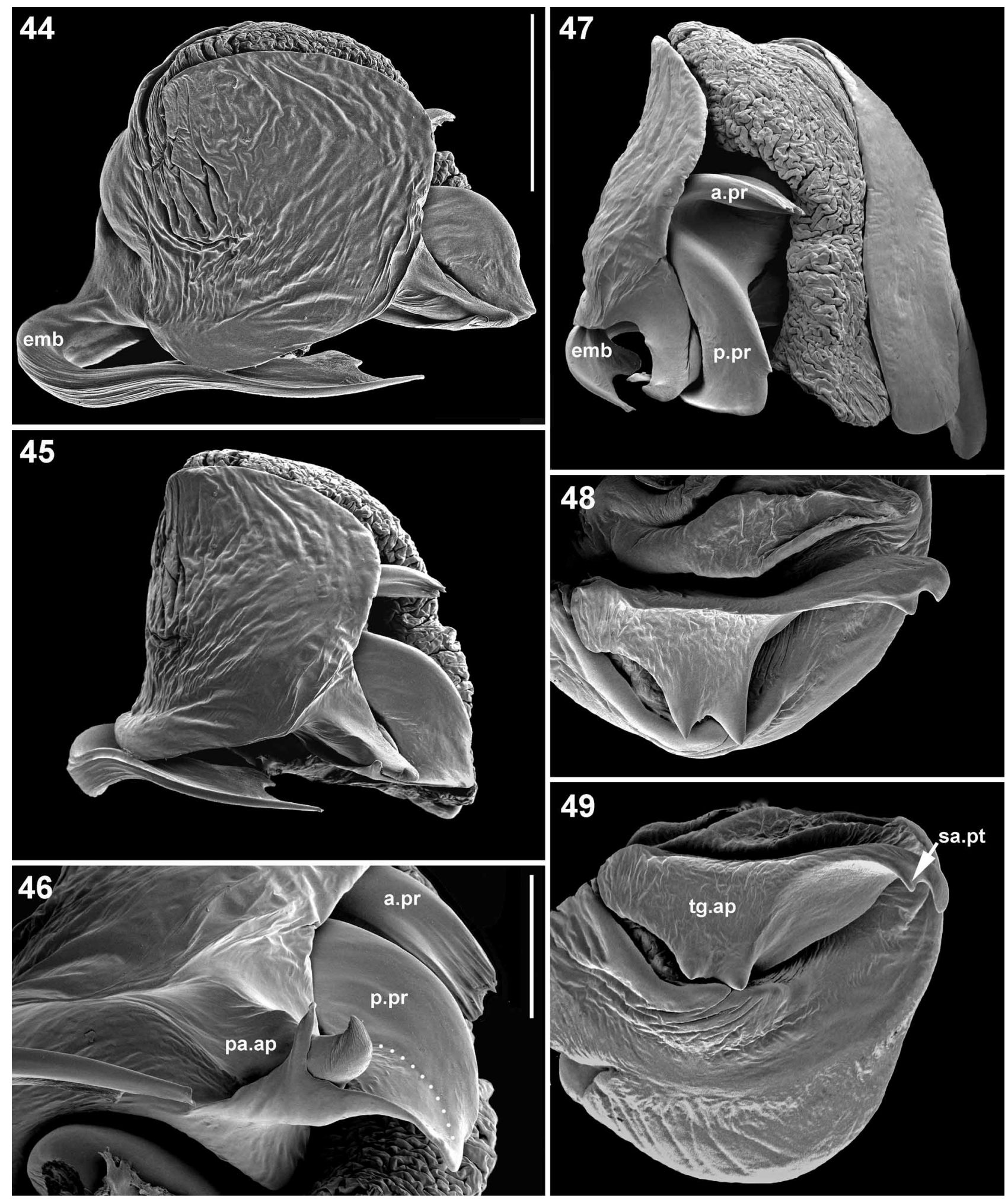

FIGURES 44-49. Draposa oakleyi (Gravely), male, from India: Ootacamund. 44. Terminal part with embolus in ventral view (note widened embolus). 45. Ditto in oblique retrolateral view. 46. Retrolateral portion of terminal part showing anterior and posterior subpaleal processes; dotted line marking extension of sclerotized part (above line) and nonsclerotized part of posterior subpaleal process. 47. Terminal part in retrolateral view. 48. Tegulum with tegular apophysis in frontal view. 49. Same in ventral view. Scale lines $200 \mu \mathrm{m}(44,45,47-49), 100 \mu \mathrm{m}(46)$.

Opisthosoma (Fig. 3). Dorsum with yellowish-grey lanceolate stripe bordered with few dark dots. Median light yellowish band behind lanceolate stripe with row of pairwise arranged dark dots, situated at each side of 
midline, continuing backwards. Dorsum on each side of light median band more or less speckled with black. Sides and venter yellowish, sides with few dark dots.

Legs (Table 1). Light brownish-yellow without annulation. TiI with two retrolateral spines.

Palp (Fig. 10, 44-49). Pt 0.50, Ti 0.50, Cy 1.15. Most of Fe, entire Ti and most of Cy greyish-brown. Apical part of $\mathrm{Fe}$, most of $\mathrm{Pt}$ and $\mathrm{Cy}$ apically yellowish. All segments with dark hairs; yellowish parts of $\mathrm{Fe}$ and Pt in addition with whitish hairs (most of which missing in males examined; cf. Gravely's statement cited in Remarks below). Bulbus at level of embolus comparatively wide. Tegular apophysis with two acute projections in basal half (Figs 48, 49, cf. D. atropalpis: Fig. 13). Posterior subpaleal process large (Figs 4547), only anterior portion (portion above dotted line in Fig. 46) sclerotised, posterior portion membraneous, with pointed process partly surrounding paleal apophysis (Fig. 46). Embolus with laminar extension along inner side terminating in a process distally (Figs 44, 45).

Female (from Ootacamund, India). Total length 4.80, carapace 2.55 long, 1.90 wide.

Prosoma and opisthosoma (Fig. 4). Similar to male in colouration. Dorsal light yellowish median band on opisthosoma, with row of black dots in pairs posterior to lanceolate stripe, more distinct than in male because sides laterad to median band more dark.

Legs (Table 1). As in male but sometimes with very weak indistinct darker annulation.

Eyes. Width of row I 41, row II 60, row III 76, row II-III 60. Diameter of AME 10, ALE 8, PME 23, PLE 18. Distance between AME 5, between AME and ALE 2.

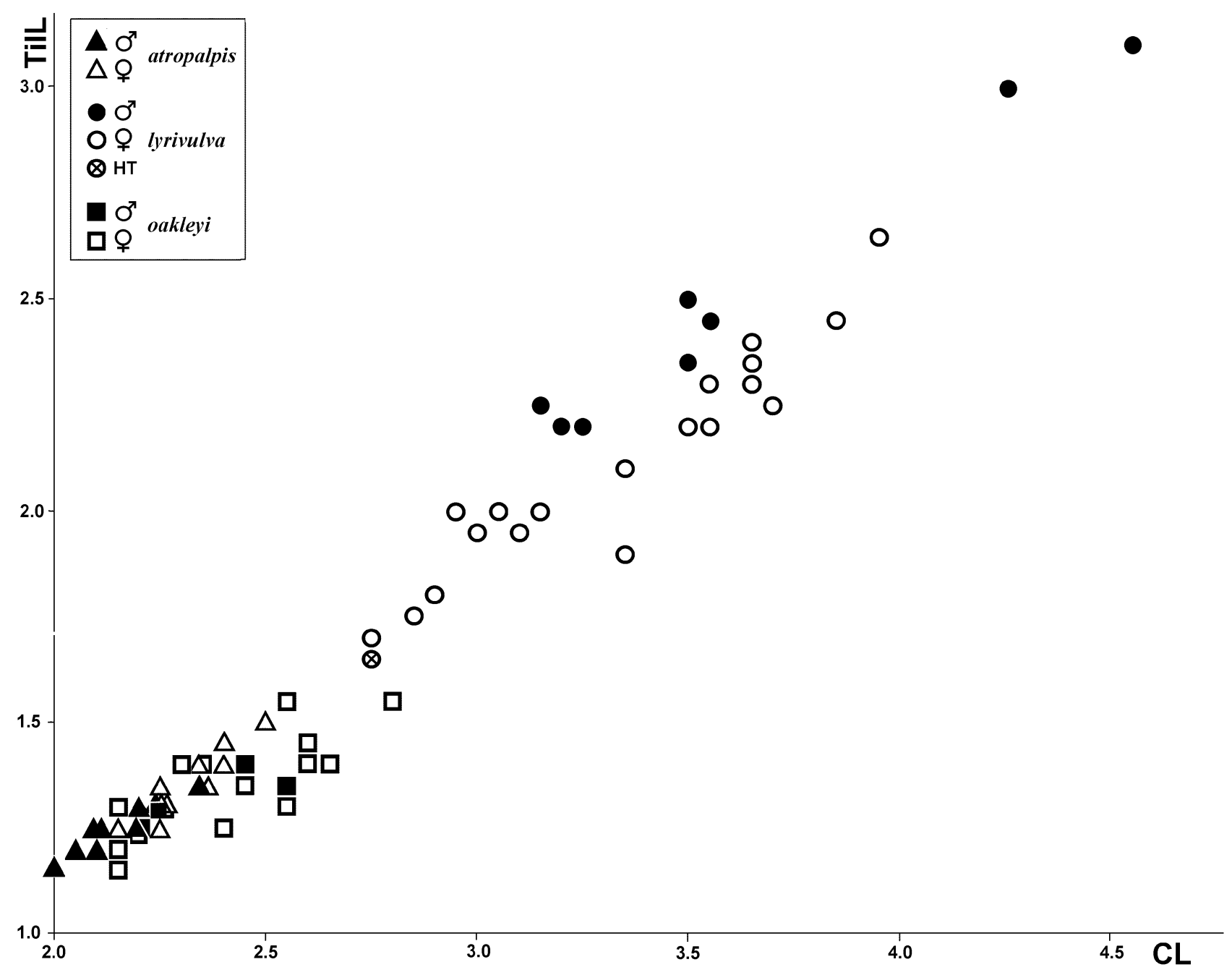

FIGURE 50. Tibia I length (TiIL)/carapace length (CL) in adult males (filled symbols) and adult females (open symbols) of Draposa atropalpis (Gravely), D. lyrivulva (Gravely) and D. oakleyi (Gravely). HT: holotype. 


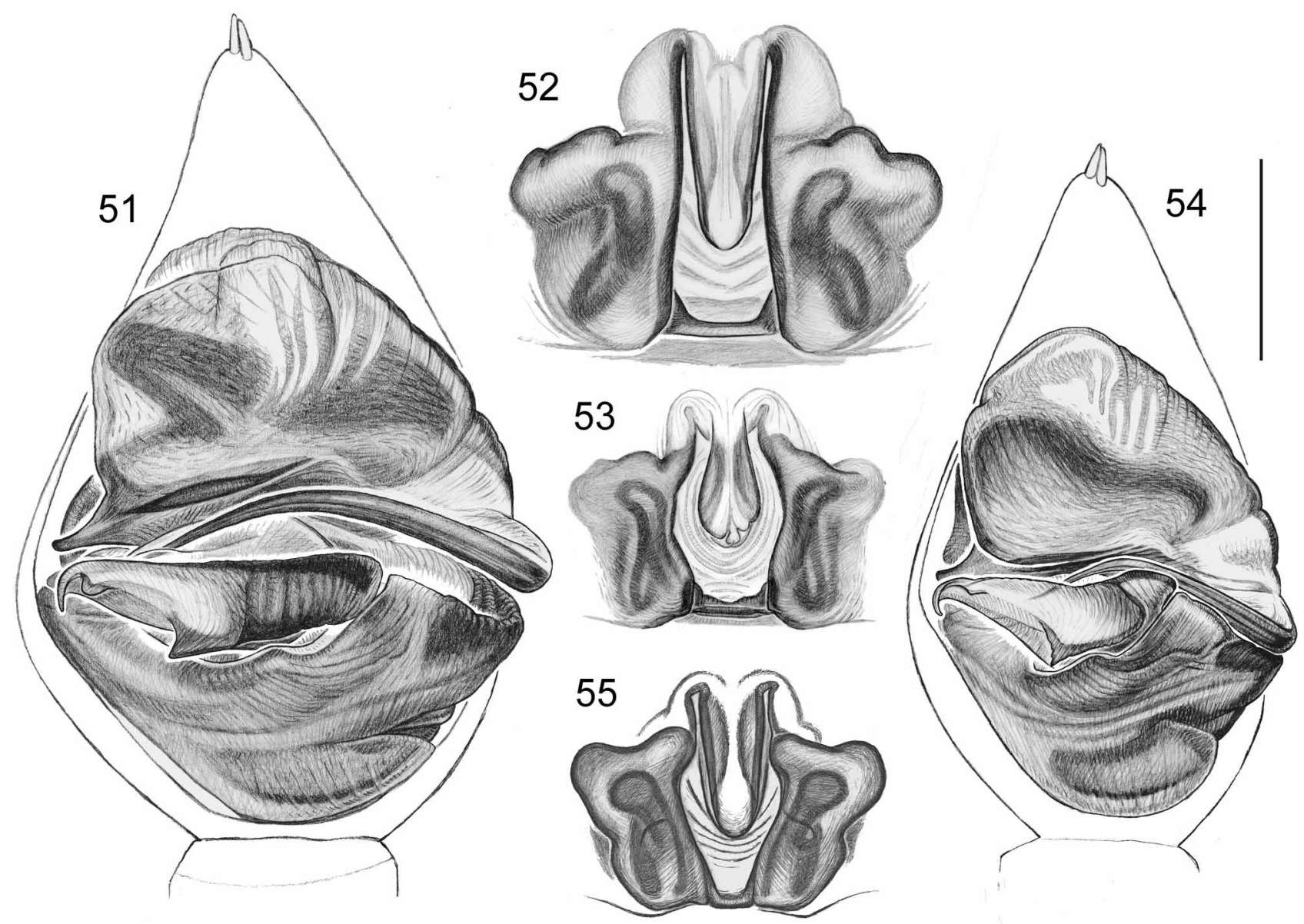

FIGURES 51-55. Right male palp, ventral view (51, 54), epigyne.(52, 53, 55). 51, 52. Draposa nicobarica (Thorell) (51 ऽ lectotype, 52 paralectotype from Nicobar: Teressa). 53. D. subhadrae (Patel \& Reddy) (from Sri Lanka: Kuchchaveli). 54, 55. D. tenasserimensis (Thorell) (54 $\widehat{\jmath}$ lectotype, 55 q paralectotype in NHRS). Scale line $0.5 \mathrm{~mm}$.

Epigyne (Figs. 21, 22, 25, cleared Fig. 31). Opening of median cavity narrow, most of it covered by a median septum. Each side with lateral elevation extending into a more or less triangle-shaped sclerite covering the receptacle. Bottom of median cavity corrugated, with characteristic shape in dorsal view (Fig. 22).

Size variation. Carapace length: males 2.20-2.55 $(n=4)$, females $2.15-2.80(n=15)$; tibia I vs. carapace length in Fig. 50.

Remarks. Gravely (1924) neither illustrated nor documented any particular details of the male apart from mentioning (p. 610) that "the male can be distinguished by the purer white pile on the upper surface of the femora of the palps, and by the continuance of this pile on to the inner side of the patella".

Tikander and Malhotra (1980) placed Pardosa lahorensis Dyal, 1935 (from Pakistan) as a synonym to $P$. oakleyi but this was not considered in Mathew et al. (2009) or listed in Platnick (2010). I support this synonymy from studying material identified as Pardosa lahorensis collected in NW India (Ludhiana), only about $150 \mathrm{~km}$ from Lahore. Pardosa oakleyi has repeatedly (e. g., Mushtaq et al. 2003) been reported as a common species in fields of various crops in Pakistan.

Sadana (1971) illustrated an inflated bulbus, which he ascribed to P. lahorensis. Although this illustration is somewhat crude, it depicts a tegular apophysis (named 'conductor'), which is characteristic in shape as for $P$. oakleyi, as well as a subpaleal sclerite (named 'terminal apophysis').

Distribution. Pakistan, India, Bangladesh. A record from Vietnam (Pham Din et al. 2007) could not be verified as part of this study. 

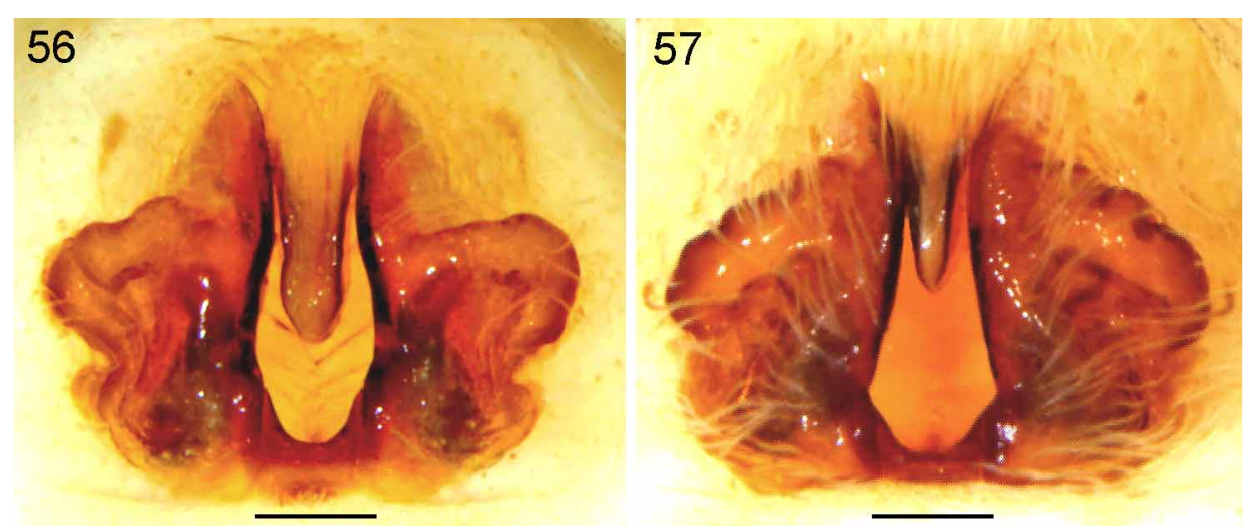

FIGURES 56 \& 57. Epigynes in ventral view. 56. Draposa cf. zhanjiangensis (Yin, Wang, Peng \& Xie) from Malaysia: Sarawak, Bako National Park. 57. Draposa sp. from Indonesia: Sumatra. Scale lines 0.2 mm.

\section{Draposa porpaensis (U. A. Gajbe, 2004) comb. nov.}

Pardosa porpaensis U. A. Gajbe, 2004: 16 figs 17-19 (ㅇ).

Type material. Holotype: + , India, Chhattisgarh, Bastar District (formerly in Madhya Pradesh), Porpa village near Jagdalpur (ca $\left.19^{\circ} 5^{\prime} \mathrm{N} 82^{\circ} 01^{\prime} \mathrm{E}\right)$ (U. A. Gajbe) (National Zoological Collection, Kolkata), not examined.

Remarks. The description and illustrations of Pardosa porpaensis hints at conspecificity with $D$. atropalpis. The shape of the epigyne, with a median short narrow septum in front (Gajbe 2004: fig. 18) as well as the colour pattern of prosoma and opisthosoma (Gajbe 2004: fig. 17) is very similar to those in $D$. atropalpis. Awaiting further study, P. porpaensis is here transferred to Draposa.

Draposa subhadrae (Patel \& Reddy, 1993) comb. nov. Figs 7, 27, 32, 42, 43, 53

Pardosa subhadrae Patel \& Reddy, 1993: 128 fig. 5 (ồ).

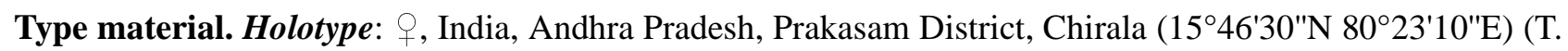
S. Reddy, National Zoological Collection, Kolkata), not examined. Patel \& Reddy (1993) mentioned $3 \bigcirc^{\lambda} 7 q$ paratypes and a second, but not precise, locality in Visakhapatnam District, Andhra Pradesh.

Material examined. SRI LANKA. Eastern: Kuchchaveli, $20 \mathrm{mi} \mathrm{NW}$ Trincomalee $\left(8^{\circ} 49^{\prime} \mathrm{N} 81^{\circ} 06^{\prime} \mathrm{E}\right)$, sandy ground, 9-10 February 1962 (loc. 60, Lund University Ceylon Expedition, MZLU, NHRS), 5 ㅇ.

Diagnosis. Female most closely related to D. lyrivulva and can be distinguished by the shape of the epigyne (Fig. 53): lateral elevations posteriorly being considerably apart and connected by sclerotised crest, and septal tongue relatively narrow (Figs $27,42,53$ ), as well as by configuration of epigynal cavity bottom as seen from inside (dorsal view: Fig. 43).

Description. Female (from Kuchchaveli, Sri Lanka). Total length 6.4 (carried egg sac). Carapace 3.35 long, 2.55 wide.

Prosoma (Fig. 7). Dorsum very light yellowish. Each side, between wide median and wide lateral band, with an irregular brownish area (dark-veined), in some specimens more or less dissolved into patches. Margins light yellow with small blackish spots (with a few dark hairs) above each leg coxa. Dark hairs in brownish parts, white hairs in light areas. Clypeus yellowish with two dark spots below first eye row. Chelicerae light brownish, frontally darker. Sternum whitish-yellow.

Eyes. Width of row I 56, row II 82, row III 98, row II-III 81. Diameter of AME, 14, ALE 10, PME 32, PLE 26. Distance between AME 6, between AME and ALE 2. 
Opisthosoma (Fig. 7). Dorsally mostly whitish (due to guanocytes); in front with yellowish brown lanceolate stripe at about half length flanked by conspicuous blackish spot at each side. (One of the females less whitish, with fewer guanocytes visible and larger spots patterned in reticulated blackish.) Dorsum with short white pubescence and stout erect, rather short dark (brownish) hairs (numerous in lanceolate stripe). Sides whitish, with or without blackish markings. Venter whitish to light yellowish with white pubescence and scattered slender, erect dark hairs.

Legs (Table 1). Very light yellowish-brown. Femora with blackish spots, in distal half with incomplete blackish ring; patellae basally dark; tibiae with wide dark basal ring and another one in distal half; metatarsi with dark basal ring and faint darkenings at the middle and distally.

TABLE 1. Leg I-IV measurements (in mm) of species of Draposa gen. nov.

\begin{tabular}{|c|c|c|c|c|c|c|}
\hline & $\mathrm{Fe}$ & $\mathrm{Pt}$ & $\mathrm{Ti}$ & Mt & $\mathrm{Ta}$ & Total \\
\hline \multicolumn{7}{|c|}{ Draposa atropalpis } \\
\hline \multicolumn{7}{|c|}{ Male } \\
\hline I & 1.60 & 0.70 & 1.30 & 1.30 & 0.90 & 5.80 \\
\hline II & 1.60 & 0.70 & 1.25 & 1.30 & 0.85 & 5.70 \\
\hline III & 1.60 & 0.65 & 1.20 & 1.50 & 0.80 & 5.75 \\
\hline IV & 2.20 & 0.80 & 1.80 & 2.65 & 1.20 & 8.65 \\
\hline \multicolumn{7}{|c|}{ Female } \\
\hline I & 1.75 & 0.80 & 1.40 & 1.30 & 0.90 & 6.15 \\
\hline II & 1.70 & 0.80 & 1.25 & 1.30 & 0.90 & 5.95 \\
\hline III & 1.65 & 0.75 & 1.25 & 1.60 & 0.85 & 6.10 \\
\hline IV & 2.35 & 0.90 & 1.90 & 2.80 & 1.25 & 9.20 \\
\hline
\end{tabular}

Draposa lyrivulva

Male

3.45

3.40

1.55

3.00

2.75

2.55

1.40

3.50

2.95

2.80

1.80

1.65

12.75

3.05

12.10

1.65

5.00

$\begin{array}{ll}1.50 & 11.65 \\ 2.10 & 16.45\end{array}$

Female

I $\quad 2.85$

1.35

2.30

2.20

2.15

1.35

10.05

1.25

2.10

1.30

9.60

III $\quad 2.60$

1.15

2.40

9.35

$1.40 \quad 3.05$

4.30

1.20

14.10

Draposa nicobarica

Male

I

II $\quad 2.90$

1.40

2.50

2.40

2.40

2.35

1.40

2.20

2.50

1.45

3.00

4.05

1.75$$
14.10
$$

III $\quad 2.75$

IV $\quad 3.60$

1.40

2.50

2.30

2.30

1.40

2.30

2.50

2.10

4.20

$\begin{array}{cc}1.40 & 10.60 \\ 1.30 & 10.35 \\ 1.20 & 9.90 \\ 1.65 & 13.80\end{array}$

1.50

3.00

1.40

10.60

$1.35 \quad 10.30$

$\begin{array}{ll}1.20 & 9.80\end{array}$

IV

2.75
3.60

1.50

1.70

14.00

Draposa oakleyi

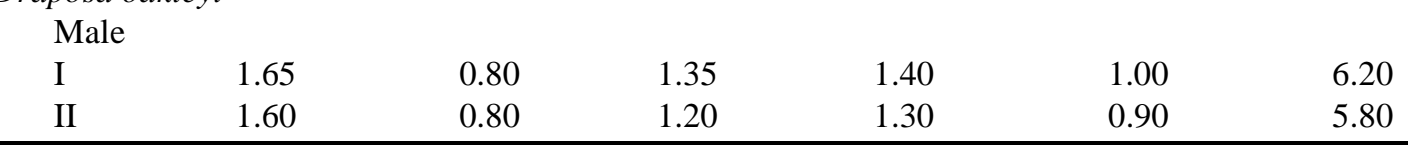

continued next page 
TABLE 1. (continued)

\begin{tabular}{|c|c|c|c|c|c|c|}
\hline & $\mathrm{Fe}$ & $\mathrm{Pt}$ & $\mathrm{Ti}$ & Mt & $\mathrm{Ta}$ & Total \\
\hline III & 1.60 & 0.75 & 1.15 & 1.50 & 0.80 & 5.80 \\
\hline IV & 2.20 & 0.90 & 1.70 & 2.50 & 1.15 & 8.45 \\
\hline \multicolumn{7}{|c|}{ Female } \\
\hline I & 1.65 & 0.85 & 1.30 & 1.25 & 0.90 & 5.95 \\
\hline II & 1.65 & 0.80 & 1.20 & 1.25 & 0.85 & 5.75 \\
\hline III & 1.60 & 0.75 & 1.20 & 1.50 & 0.80 & 5.85 \\
\hline IV & 2.25 & 0.90 & 1.90 & 2.70 & 1.20 & 8.95 \\
\hline \multicolumn{7}{|c|}{ Draposa subhadrae } \\
\hline \multicolumn{7}{|c|}{ Female } \\
\hline I & 2.60 & 1.20 & 2.25 & 2.10 & 1.40 & 9.55 \\
\hline II & 2.60 & 1.20 & 2.10 & 2.15 & 1.35 & 9.40 \\
\hline III & 2.55 & 1.15 & 2.10 & 2.45 & 1.25 & 9.50 \\
\hline IV & 3.50 & 1.35 & 3.10 & 4.35 & 1.70 & 14.00 \\
\hline \multicolumn{7}{|c|}{ Draposa tenasserimensis } \\
\hline \multicolumn{7}{|c|}{ Male } \\
\hline I & 2.95 & 1.40 & 2.55 & 2.50 & 1.55 & 10.95 \\
\hline II & 2.90 & 1.35 & 2.40 & 2.45 & 1.50 & 10.60 \\
\hline III & 2.75 & 1.25 & 2.20 & 2.60 & 1.30 & 10.10 \\
\hline IV & 3.60 & 1.50 & 3.10 & 4.40 & 1.85 & 14.45 \\
\hline \multicolumn{7}{|c|}{ Female } \\
\hline I & 2.45 & 1.15 & 2.00 & 1.85 & 1.20 & 8.65 \\
\hline II & 2.35 & 1.10 & 1.85 & 1.85 & 1.15 & 8.30 \\
\hline III & 2.25 & 1.05 & 1.70 & 2.05 & 1.05 & 8.10 \\
\hline IV & 3.10 & 1.20 & 2.60 & 3.60 & 1.50 & 12.00 \\
\hline
\end{tabular}

Epigyne (Figs 27, 32, 42, 43, 53). Conspicuous deep median cavity divided in front by a septum. Rims of lateral elevations posteriorly apart, with a wider sclerotized crest in between them (cf. P. lyrivulva). Cavity bottom corrugated, of characteristic shape in dorsal view. Spermathecal stalks long, anteriorly terminating in head of spermatheca bent outwards (Fig. 32).

Size variation. Carapace length $2.85-3.35(n=5)$.

Remarks. This species was described from both sexes. The description and illustrations of the male, however, do not show enough specific details.

From the original description of the female sex, notably the shape of the epigyne and the annulation of the legs, I ascribe the material at hand from Sri Lanka to D. subhadrae rather than to an undescribed species.

Distribution. India, Sri Lanka.

Draposa tenasserimensis (Thorell, 1895) comb. nov.

Figs 28, 54, 55

Lycosa tenasserimensis Thorell, 1895: 239-242.

Pardosa tenasserimensis: Roewer 1955: 184.

Type material. Lectotype (designated here) of Lycosa tenasserimensis Thorell, 1895: О, Myanmar "Tenasserim meridionali" (Oates, Collectio Thorell No. 247/1559, NHRS), examined. Paralectotypes of Lycosa tenasserimensis Thorell, 1895: 1§,1 + , same data as lectotype; $2 \AA, 2+$, Myanmar, "Southern Tenasserim" (Oates, BM 1898.9.21.795-798, BMNH), all examined.

Diagnosis. Males may be distinguished by configuration of tegular apophysis, with one acute protrusion in proximal half (Fig. 54), but considerably shorter in length compared with D. nicobarica (cf. Fig. 51); 
females by shape of opening to epigyneal cavity, being wide in anterior part and gradually narrowing posteriad (Figs $28 \& 55$ ).

Description. Male (lectotype). Total length $7.2 \mathrm{~mm}$. Carapace $3.80 \mathrm{~mm}$ long, $2.80 \mathrm{~mm}$ wide.

Prosoma. Dorsum brownish, with yellowish median and lateral bands. Median band dilated in postocular area and in this part with two brownish stripes or spots at each side of midline. Lateral bands wide, with 2-3 brownish spots at carapace margin. Median band with short dark hairs and recumbent white pubescence, brownish sides and marginal spots with short dark hairs, lateral bands with whitish pubescence. Clypeus yellowish (traces of darker coloration below ALEs). Chelicerae yellowish brown. Sternum yellowish.

Eyes. Width of row I 59, row II 85, row III 109, row II--III 83. Diameter of AME13, ALE 10, PME 34, PLE 28. Distance between AME 8, between AME and ALE 3.

Opisthosoma. Dorsum brownish, medially with a regular pattern of yellowish spots surroundiung lanceolate stripe and continuing backwards. Lanceolate stripe yellowish, margined by grey brownish dots and elongated patches. Sides and venter yellowish.

Legs (Table 1). Light yellowish (bleached) with faint traces of annulation. TiI with two retrolateral spines.

Palp (Fig. 54). Pt 0.70, Ti 0.60, Cy 1.70. Cymbium somewhat flattened towards retrolateral side. Orientation of dorsal hairs on cymbium similar to condition in D. lyrivulva (cf. Fig. 37). Tegular apophysis moderately long, with one acute tooth-like projection in basal half. Embolus long and narrow.

Female (from "Tenasserim meridionali", Myanmar). Total length $6.0 \mathrm{~mm}$ (carried egg sac). Carapace 3.30 mm long, $2.40 \mathrm{~mm}$ wide.

Prosoma and opisthosoma. Coloration and pattern essentially as in male.

Eyes. Width of row I 52, row II 76, row III 96, row II-III 74. Diameter of AME 12, ALE 9, PME 30, PLE 25. Distance between AME 6, between AME and ALE 3.

Legs (Table 1). Yellowish with light brown annulation. TiI with 2 retrolateral spines.

Epigyne (Figs 28, 55). Septum extending to more than half the length of epigynal opening and epigynal opening widest in anterior half, with lateral elevations converging posteriad. Rounded heads of spermathecae and stalks of spermathecae visible through cuticle of lateral elevations.

Size variation. Carapace length: males 3.55-3.80 $(n=4)$, females 3.10-3.35 $(n=3)$.

Distribution. Myanmar. The records from Indonesia [Sumatra (Reimoser 1927), Java (Reimoser 1931), sub Lycosa tenasserimensis] are uncertain. Other species of Draposa are present in Malaysia and Indonesia (cf. Remarks under $D$. zhanjiangensis below).

\section{Draposa zhanjiangensis (Yin, Wang, Peng \& Xie, 1995) comb. nov.}

Pardosa zhanjiangensis Yin, Wang, Peng \& Xie, 1995: 74, 77, figs 18-22 (ð우). Yin et al. 1997: 281, fig. 133 (§゚ㅇ, identical with previous reference). Song et al.1999, figs 199Q, 200B ( $\widehat{\jmath}$ + from Yin et al. 1995).

Type material. Holotype $\odot$ : China, Guangdong Province, Zhanjiang City $\left(21^{\circ} 12^{\prime} \mathrm{N}\right.$ $\left.110^{\circ} 24^{\prime} \mathrm{E}\right)$ (together with $1{ }^{\Uparrow} 19$ paratypes) in Hunan Biology Research Institute, Changsha, not examined.

Diagnosis. Male may be distinguished by shape of tegular apophysis, notably the somewhat squared projection in the basal half (Yin et al. 1995 , fig. 22; Yin et al. 1997, fig. 133e) [acute projection(-s) in the other known congenerics], female by shape of epigyne, notably size and form of tongue-like septum (Yin $e t$ al. 1995, fig. 19; Yin et al. 1997, fig. 133b; Song et al. 1999, fig. 200B).

Remarks. The illustrations supplied with the original description show details typical for the genus Draposa, e. g., the shape of the tegular apophysis and the presence of a subpaleal sclerite in the male palp as well as the shape of the epigyne, with a tongue-like septum, in the female (Yin et al.: references above)

Material of a congener from Malaysia [Sarawak, Bako National Park $\left(1^{\circ} 44^{\prime} \mathrm{N} 110^{\circ} 28^{\prime} \mathrm{E}\right)$, grassy patch on sandy seashore, 17 October 1979 (K. \& B.Bremer), $1{ }^{\Uparrow} 4$ (Fig. 56)] and Indonesia [Belitung (2॰50'S

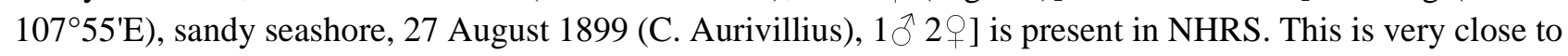
or conspecific with Draposa zhanjiangensis. Norma-Rashid \& Li (2009) reported specimens identified as D. zhanjiangensis from the island of Tioman off the east coast of Peninsular Malaysia. Comparison with Chinese specimens should be undertaken in order to confirm conspecificity. Two females of Draposa in NHRS from 
Indonesia [Sumatra, Medan $\left(3^{\circ} 35^{\prime} \mathrm{N} 98^{\circ} 40^{\prime} \mathrm{E}\right), 1920$ (E. Mjöberg)] have epigynes with a considerably shorter tongue-like septum (Fig. 57) compared with D. zhanjiangensis from China (Yin et al.: references above) and the material from Sarawak (Fig. 56); these specimens may belong to a close, presumably undescribed species.

Distribution. China: Guangdong (but see Remarks above).

\section{Acknowledgements}

Thanks are due to Mrs Janet Beccaloni (BMNH), Dr Lennart Cederholm (MZLU), Dr Peter Jäger (SMF), Dr Pekka T. Lehtinen (ZMUT), and Dr Nikolaj Scharff (ZMUC) for loan of material in their care, to Dr Yuri M. Marusik, Magadan, Russia, for help with some of the photos and literature, to Mr. Louis Sorkin (American Museum of Natural History, New York, USA) for help with literature, and to Dr. Hozumi Tanaka, Osaka, Japan, for information. Professors Kåre and Birgitta Bremer, University of Stockholm, Sweden, are thanked for material from Borneo. I am grateful to Dr Volker Framenau (Western Australian Museum, Welshpool, Australia), Dr Lehtinen, Dr Marusik and Dr Luis Piacentini (Museo Argentino de Ciencias Naturales "Bernadino Rivadavia", Buenos Aires, Argentina) who all commented on, and in various ways, improved the manuscript. Special thanks go to Ms. Andrea Klintbjer, formerly at NHRS, for her very skilful drawings.

\section{References}

Alderweireldt, M. \& Jocqué, T. (1992) A review of the nebulosa-group of Pardosa Koch 1847 in Africa, a complex with some highly variable species (Araneae Lycosidae). Tropical Zoology, 5, 73-113.

Bösenberg, W. \& Strand, E. (1906) Japanische Spinnen. Abhandlungen Herausgegeben von der Senckenbergischen Naturforschenden Gesellschaft, 30, 93-422.

Brinck, P., Andersson, H. \& Cederholm, L. (1971) Report No. 1 from the Lund University Ceylon expedition in 1962. Entomologica Scandinavica, Suppl. 1, iii-xxxvi.

Chen, J., Song, D.X. \& Li, S.Q. (2001) A new species of the genus Pardosa from China (Araneae: Lycosidae). Acta Zootaxonomica Sinica, 26, 476-478.

Dondale, C.D. (1986) The subfamilies of wolf spiders (Araneae: Lycosidae). Actas X Congreso Internacional de Aracnología, 1, 327-332.

Dondale, C.D. \& Redner, J.H. (1990) The insects and arachnids of Canada, Part 17. The wolf spiders, nurseryweb spiders, and lynx spiders of Canada and Alaska (Araneae: Lycosidae, Pisauridae, and Oxyopidae). Research Branch, Agriculture Canada, Publication, 1856, 1-383.

Dyal, S. (1935) Fauna of Lahore. 4. Spiders of Lahore. Bulletin of the Department of Zoology Panjab University, 1: i-ii+119252.

Gajbe, U.A. (2004) Studies on some spiders of the family Lycosidae (Araneae: Arachnida) from Madhya Pradesh, India. Records of the Zoological Society of India, Occasional Papers, 221, 1-40.

Gravely, F.H. (1924) Some Indian spiders of the family Lycosidae. Records of the Indian Museum, 26, 587-613.

Juberthie-Jupeau, L., Lopez, A. \& Kronestedt, T. (1990) Structure et ultrastructure de la glande tibiale chez le mâle d'Alopecosa cuneata (Clerck) (Araneae, Lycosidae). Revue Arachnologique, 9, 63-77.

Kronestedt, T. (1975) Studies on species of Holarctic Pardosa groups (Araneae, Lycosidae). I. Redescription of Pardosa albomaculata Emerton and description of two new species from North America, with comments on some taxonomical characters. Zoologica Scripta, 4, 217-228.

Kronestedt, T. (1986) A presumptive pheromone-emitting structure in wolf spiders (Araneae, Lycosidae). Psyche, Cambridge, 93, 127-131.

Kronestedt, T. (1987) On some African and Oriental wolf spiders (Araneae, Lycosidae): redescription of Pardosa oncka Lawrence from Africa, with notes on its generic position. Journal of Natural History, 21, 967-976.

Kronestedt, T., Dondale, C.D. \& Zyuzin, A.A. (2002) Pardosa C. L. Koch, 1847 (Arachnida, Araneae): proposed fixation of Lycosa alacris C. L. Koch, 1833 as the type species to conserve the usage of Pardosa and of Alopecosa Simon, 1885. Bulletin of Zoological Nomenclature, 59, 7-11.

Marusik, Y.M., Azarkina, G. \& Koponen, S. (2003) A survey of East Palaearctic Lycosidae (Aranei). II. Genus Acantholycosa F. Dahl, 1908 and releated new genera. Arthropoda Selecta, 12, 101-148.

Mathew M.J., Sebastian, P.A. \& Sunish, E. (2009) Updated checklist of Indian spiders. In: Sebastian, P. A. \& Peter, K. V. (eds) Spiders of India, Universities Press, Hyderabad, pp. 432-603.

Murphy, N.P., Framenau, V.W., Donnellan, S.C., Harvey, M.S., Park, Y.-C. \& Austin, A.D. (2006) Phylogenetic reconstruction of the wolf spiders (Araneae: Lycosidae) using sequences from the 12S rRNA, 28S rRNA, and NADH1 
genes: Implications for classification, biogeography, and the evolution of web building behavior. Molecular Phylogenetics and Evolution, 38, 583-602.

Mushtaq, S., Beg, M.A. \& Aziz, S. (2003) Biodiversity and temporal variations in the abundance of cursorial spiders of a cotton field at Faisalabad. Pakistan Journal of Zoology, 35, 125-131.

Norma-Rashid, Y. \& Li, D. (2009) A checklist of spiders (Arachnida: Araneae) from Peninsular Malaysia inclusive of twenty new records. The Raffles Bulletin of Zoology, 57, 305-322.

Okuma, C., Kamal, N.Q., Hirashima, Y., Alam, M.Z. \& Ogata, K. (1993) Illustrated Monograph of the Rice Field Spiders of Bangladesh. Institute of Postgraduate Studies in Agriculture (Salna, Gazipur, Bangladesh) ? Japan International Cooperation Agency Project Publication 1, 93 pp.

Patel, B.H. \& Reddy, T.S. (1993) On some new species of spiders of the genera Hippasa Simon, Lycosa Latreille, Pardosa Koch and Trochosa Koch (family: Lycosidae) from coastal Andhra Pradesh, India. Records of the Zoological Survey of India, 90, 121-133.

Pham Dinh, S., Xu, X. \& Li, S.-Q. (2007) A preliminary note on spider fauna of Vietnam (Arachnida: Araneae). Acta Arachnologica Sinica, 16, 121-128.

Platnick, N.I. (2010) The World Spider Catalog, version 11.0. American Museum of Natural History, online at http:// research.amnh.org/entomology/spiders/catalog/index.html (accessed 24 August 2010).

Ponomarev, A.V., Belosludtsev, E.A. \& Dvadnenko, K.V. (2008) Spiders (Aranei) of the Lower Volga Region (Astrakhan and Volgograd areas of Russia) with the description of new taxa. Caucasian entomological Bulletin, 4, 163-185 (In Russian with English title and abstract.)

Reimoser, E. (1927) Spinnen von Sumatras Ostküste. Miscellanea Zoologica Sumatrana, 13, 1-6.

Reimoser, E. (1931) Echte Spinnen der deutschen limnologischen Sunda-Expedition. Archiv für Hydrobiologie, 8 (Suppl.), 759-770.

Roewer, C.F. (1955) Katalog der Araneae von 1758 bis 1940, bzw. 1954. 2. Band, Abteilung A (Lycosaeformia, Dionycha [excl. Salticiformia]). Institut Royal des Sciences Naturelles de Belgique, Bruxelles, 2a, 1-923.

Russell-Smith, A., Alderweireldt, M. \& Jocqué, R. (2007) On the new genus Foveosa accommodating the Afrotropical wolf spiders related to Pardosa foveolata (Araneae: Lycosidae). Journal of Afrotropical Zoology, 3, 59-76.

Sadana, G.L. (1971) Method for expanding of the palpal organs of spiders. Science and Culture, 37, $106-107$.

Sierwald, P. (2000) Description of the male of Sosippus placidus, with notes on the subfamily Sosippinae (Araneae, Lycosidae). Journal of Arachnology, 28, 133-140.

Sinha, T.B. (1951) On the collection of lycosid spiders in the Zoological Survey of India, (Indian Museum) with critical notes on the species. Records of the Indian Museum, 48, 9-52.

Song, D.X., Zhu, M.S. \& Chen, J. (1999) The Spiders of China. Hebei Science and Technology Publishing House, Shijiazhuang.

Strand, E. (1907) Süd- und ostasiatische Spinnen. Abhandlungen der Naturforschenden Gesellschaft zu Görlitz, 25, $107-215$.

Strand, E, (1909) Süd- und ostasiatische Spinnen. Abhandlungen der Naturforschenden Gesellschaft zu Görlitz, $26,1-128$.

Tanaka, H. (1993) Lycosid spiders of Japan XII. The genus Pardosa C. L. Koch-pullata-group and P. lyrivulva. Acta Arachnologica, 42, 173-179.

Tanaka, H. (2009) Lycosidae. In: Ono, H. (ed.): The spiders of Japan with keys to the families and genera and illustrations of the species. Tokai University Press, Kanagawa, pp. 222-248. (In Japanese).

Thorell, T. (1891) Spindlar från Nikobarerna och andra delar af södra Asien till större delen insamlade under K. danska korvetten Galatheas resa omkring jorden åren 1845-1847. Kongliga Svenska Vetenskapsakademiens Handlingar, (N. F.) 24 (2), 1-149.

Thorell, T. (1895) Descriptive Catalogue of the Spiders of Burma. British Museum. London, 406 pp.

Tikader, B.K. (1977) Studies on spider fauna of Andaman and Nicobar Islands, Indian Ocean. Records of the Zoological Survey of India, 72, 153-212.

Tikader, B.K. \& Malhotra, M.S. (1976) Studies on some spiders of the genus Pardosa Koch from India (family: Lycosidae). Proceedings of the Indian Academy of Sciences, 83B (3), 123-131.

Tikader, B.K. \& Malhotra, M.S. (1980) Lycosidae (Wolf-spiders). Fauna of India (Araneae), 1, 248-447.

Yaginuma, T. (1986) Spiders of Japan in Color (new ed.). Hoikusha Publishing Company, Osaka, 305 pp., 64 pls. (In Japanese).

Yin, C.M., Wang, J.F., Peng, X.J. \& Xie, L.P. (1995) Four new species of the genus Pardosa (Araneae: Lycosidae) from China. Acta Scientiarum Naturalium Universitatis Normalis Hunanensis, 18 (4), 72-78. (In Chinese with English abstract).

Yin, C.M., Peng, X.J., Xie, L.P., Bao, Y.H. \& Wang, J.F. (1997) Lycosids in China. Hunan Normal University Press, Changsha, 317 pp. (In Chinese).

Zyuzin, A.A. (1985) [Generic and subfamilial criteria in the systematics of the spider family Lycosidae (Aranei), with the description of a new genus and two new subfamilies.] Trudy Zoologicheskogo Instituta, Leningrad, 139, 40-51. (In Russian with English abstract).

Zyuzin, A.A. (1993) Studies on the wolf spiders (Araneae: Lycosidae). I. A new genus and species from Kazakhstan, with comments on the Lycosinae. Memoirs of the Queensland Museum, 33, 693-700. 